\title{
Cdk5-Dependent Phosphorylation of $\mathrm{Ca}_{\mathrm{v}} 3.2 \mathrm{~T}$-Type Channels: Possible Role in Nerve Ligation-Induced Neuropathic Allodynia and the Compound Action Potential in Primary Afferent C Fibers
}

\author{
๑Kimberly Gomez, ${ }^{1 \star}$ Aida Calderón-Rivera, ${ }^{2 *}$ Alejandro Sandoval, ${ }^{2}$ Ricardo González-Ramírez, ${ }^{3}$ \\ Alberto Vargas-Parada, ${ }^{1}$ Julia 0jeda-Alonso, ${ }^{1}$ OVinicio Granados-Soto, ${ }^{4}$ Rodolfo Delgado-Lezama, ${ }^{1}$ \\ and $\odot$ Ricardo Felix ${ }^{5}$ \\ ${ }^{1}$ Department of Physiology, Biophysics and Neuroscience, Centre for Research and Advanced Studies (Cinvestav), 07000 Mexico City, Mexico, ${ }^{2}$ School of \\ Medicine, Facultad de Estudios Superiores Iztacala, National Autonomous University of Mexico (UNAM), 54090 Tlalnepantla, Mexico, ${ }^{3}$ Department of \\ Molecular Biology and Histocompatibility, "Dr. Manuel Gea González” General Hospital, 14080 Tlalpan, Mexico, ${ }^{4}$ Neurobiology of Pain Laboratory, \\ Departmento de Farmacobiología, Cinvestav, Sede Sur, 14330 Tlalpan, Mexico, and 5epartment of Cell Biology, Cinvestav, 07360 Mexico City, Mexico
}

Voltage-gated T-type $\mathrm{Ca}^{2+}\left(\mathrm{Ca}_{\mathrm{V}} 3\right)$ channels regulate diverse physiological events, including neuronal excitability, and have been linked to several pathological conditions such as absence epilepsy, cardiovascular diseases, and neuropathic pain. It is also acknowledged that calcium/calmodulin-dependent protein kinase II and protein kinases A and C regulate the activity of T-type channels. Interestingly, peripheral nerve injury induces tactile allodynia and upregulates $\mathrm{Ca}_{\mathrm{V}} 3.2$ channels and cyclin-dependent kinase 5 (Cdk5) in dorsal root ganglia (DRG) and spinal dorsal horn. Here, we report that recombinant $\mathrm{Ca}_{\mathrm{V}} 3.2$ channels expressed in HEK293 cells are regulatory targets of Cdk5. Site-directed mutagenesis showed that the relevant sites for this regulation are residues S561 and S1987. We also found that Cdk5 may regulate $\mathrm{Ca}_{\mathrm{v}} 3.2$ channel functional expression in rats with mechanical allodynia induced by spinal nerve ligation (SNL). Consequently, the Cdk5 inhibitor olomoucine affected the compound action potential recorded in the spinal nerves, as well as the paw withdrawal threshold. Likewise, Cdk5 expression was upregulated after SNL in the DRG. These findings unveil a novel mechanism for how phosphorylation may regulate $\mathrm{Ca}_{\mathrm{V}} 3.2$ channels and suggest that increased channel activity by Cdk5-mediated phosphorylation after SNL contributes nerve injury-induced tactile allodynia.

Key words: allodynia; calcium channels; neuropathic pain; spinal nerve ligation

Significance Statement

Neuropathic pain is a current public health challenge. It can develop as a result of injury or nerve illness. It is acknowledged that the expression of various ion channels can be altered in neuropathic pain, including $\mathrm{T}$-type $\mathrm{Ca}^{2+}$ channels that are expressed in sensory neurons, where they play a role in the regulation of cellular excitability. The present work shows that the exacerbated expression of Cdk5 in a preclinical model of neuropathic pain increases the functional expression of $\mathrm{Ca}_{\mathrm{v}} 3.2$ channels. This finding is relevant for the understanding of the molecular pathophysiology of the disease. Additionally, this work may have a substantial translational impact, since it describes a novel molecular pathway that could represent an interesting therapeutic alternative for neuropathic pain.

\section{Introduction}

Pain is a relevant clinical problem and, in its chronic form, can represent a serious disability condition. According to the World
Health Organization, $\sim 20 \%$ of primary care patients have chronic pain (Yawn et al., 2009). This condition results from injury and/or abnormal functioning of the nervous system that

K.G., A.V.-P., and J.0.-A., as well as from DGAPA-UNAM to A.C.-R. We thank the two anonymous reviewers for their many insightful comments and suggestions on the manuscript.

*K.G. and A.C.-R. contributed equally to this work.

The authors declare no competing financial interests.

Correspondence should be addressed to Ricardo Felix at rfelix@cinvestav.mx.

https://doi.org/10.1523/JNEUROSCI.0181-19.2019

Copyright $\odot 2020$ the authors 
begins to interpret normal sensory stimuli (i.e., temperature, touch) as painful sensations (Millan, 1999; Woolf, 2004). These stimuli are detected by a subpopulation of primary afferent fibers $(\mathrm{C}$ and $\mathrm{A} \delta$ ) called nociceptors whose somas are located in the dorsal root ganglia (DRG; Basbaum et al., 2009). Sensory neurons have a pseudounipolar morphology with a peripheral branch that innervates its target tissue and a central branch that establishes synapses in the dorsal horn of the spinal cord (Millan, 1999; Woolf, 2004; Todd, 2010).

Although the pathophysiology of neuropathic pain is far from being understood, recent studies suggest that voltage-gated $\mathrm{Ca}^{2+}$ $\left(\mathrm{Ca}_{\mathrm{V}}\right)$ channels play crucial roles in nociceptive signaling. A subpopulation of DRG neurons does not express high voltageactivated (HVA) currents but do have low-threshold (T-type) currents. Most small-diameter DRG neurons and the T-rich cells express capsaicin-sensitive T-currents and are positive for lectin IB4, suggesting their nociceptive function. T-channels are also present in medium-diameter DRG neurons (Nelson et al., 2006, 2007). It has been reported that $\mathrm{Ca}_{\mathrm{V}} 3.2$ is the most abundant isoform of the T-channels in nociceptive neurons of small and medium diameters (Scroggs and Fox, 1992; Talley et al., 1999), and are present in the central terminals of peptidergic and nonpeptidergic fibers that synapse in the dorsal horn of the spinal cord (Jacus et al., 2012). Also, these channels are expressed in the cutaneous mechanoreceptors of low-threshold (A $\delta$ and C) fibers both in the initial segment of the axon and in the peripheral terminals that make contact at presynaptic and postsynaptic levels in the spinal cord (François et al., 2015).

T-type channels are regulated by phosphorylation (Lambert et al., 2006; Chemin et al., 2007; Blesneac et al., 2015). The intracellular loop connecting domains II and III of the pore-forming subunit is an important modulation site for different protein kinases, including calcium/calmodulin-dependent protein kinase II and protein kinases $\mathrm{A}$ and $\mathrm{C}$, that generally increase current density (Yao et al., 2006; Iftinca and Zamponi, 2009; Zhang et al., 2013). Also, a role for cyclin-dependent kinase 5 (Cdk5) in the regulation of T-channels in neuroblastoma N1E-115 cells and recombinant $\mathrm{Ca}_{\mathrm{V}} 3.1$ channels expressed in HEK293 cells has been recognized (Calderón-Rivera et al., 2015). Cdk5 is a ubiquitously expressed kinase that forms a catalytic complex with its activators p35 and p39 (McLinden et al., 2012).

Interestingly, an increase in $\mathrm{Ca}_{\mathrm{V}} 3.2$ channels and $\mathrm{T}$-currents has been observed in DRG and dorsal horn neurons from rats with neuropathic pain (Jagodic et al., 2008; Takahashi et al., 2010; Wen et al., 2010). Consistent with this, intrathecal administration of antisense $\mathrm{Ca}_{\mathrm{V}} 3.2$ oligonucleotides or the T-channel blocker mibefradil prevents neuropathic pain induced by sciatic nerve constriction or DRG compression (Dogrul et al., 2003; Bourinet et al., 2005; Wen et al., 2010). Likewise, an increase in $\mathrm{Ca}_{\mathrm{V}} 3.2$ channel and T-current expression has also been observed in DRG and spinal cord neurons from animals with diabetic neuropathy, and its knockdown in the DRG prevents hyperalgesia (Jacus et al., 2012; Todorovic and Jevtovic-Todorovic, 2013).

Here, we investigated the modulation of T-channels by the Cdk5/p35 complex expressed in HEK293 cells, and their role in the excitability of the sensory fibers, by analyzing the compound action potential (cAP) evoked by stimulation of the spinal nerve L5 and recorded in the corresponding dorsal root of animals with allodynia induced by ligation of the spinal nerves L5-L6. We found an increase in the amplitude of the $\mathrm{C}$ component of the cAP, related to an increase in the functional expression of the $\mathrm{Ca}_{\mathrm{V}} 3.2$ channels induced by Cdk5-mediated phosphorylation. In addition, intrathecal administration of a Cdk5 inhibitor allevi- ated mechanical allodynia and decreased the $\mathrm{C}$ component of the cAP.

\section{Materials and Methods}

Cell culture. Human embryonic kidney (HEK) 293 cells were grown as previously described (Calderón-Rivera et al., 2015). In brief, untransfected cells were kept in DMEM-HG culture medium containing $25 \mathrm{~mm}$ glucose, supplemented with $10 \%$ fetal bovine serum (FBS), $2 \mathrm{~mm}$ L-glutamine, and antibiotics. HEK293 cells stably expressing the $\mathrm{Ca}_{\mathrm{V}} 3.2$ channels were maintained in culture in DMEM supplemented with 1 $\mathrm{mg} / \mathrm{ml}$ G418 (Thermo Fisher Scientific), 10\% FBS, and penicillinstreptomycin $(100 \mathrm{U} / \mathrm{ml})$ also at $37^{\circ} \mathrm{C}$ in a $5 \% \mathrm{CO}_{2}-95 \%$ air humidified atmosphere. The cells were treated with olomoucine at a final concentration of $100 \mu \mathrm{M}$ during $48 \mathrm{~h}$ or with DMSO (as control). Both cell cultures were reseeded by mechanical dispersion every week.

Whole-cell patch-clamp electrophysiology. HEK293 cells were subjected to the whole-cell mode of the patch-clamp technique using an Axopatch 200B amplifier as described previously (Avila et al., 2004; CalderónRivera et al., 2015). Current signals were filtered and digitized at 2 and 5.7 $\mathrm{kHz}$, respectively, and analyzed with pCLAMP software (Molecular Devices). The bath recording solution contained the following (in $\mathrm{mm}$ ): either $5 \mathrm{CaCl}_{2}$ (stably transfected cells) or $10 \mathrm{BaCl}_{2}$ (transiently transfected cells), 125 TEA-Cl, 10 HEPES, and 10 glucose, $\mathrm{pH}$ 7.3. The pipette solution contained the following (in mM): $110 \mathrm{CsCl}, 5 \mathrm{MgCl}_{2}, 10 \mathrm{EGTA}$, 10 HEPES, 4 Mg-ATP, and 0.1 GTP, pH 7.3. Recording pipettes with resistance values in the range of 2-3 $\mathrm{M} \Omega$ were used. Both the linear leak and the parasitic capacitance components were subtracted using a $\mathrm{P} / 4$ standard protocol. Membrane capacitance $\left(C_{\mathrm{m}}\right)$ was determined as previously described and used to normalize currents (Avila et al., 2004).

Current activation curves were fitted using the following equation: $G / G_{\max }=1 /\left\{1+\exp \left[\left(V-V_{1 / 2}\right) / k\right]\right\}$, where $G$ is peak conductance, $G_{\max }$ is maximal conductance, $V_{1 / 2}$ is half-activation voltage, and $k$ is a slope factor. Current steady-state inactivation curves were fitted with the following equation: $I / I_{\max }=1 /\left(1+\exp \left(-\left(V_{\mathrm{m}}-V_{1 / 2 \text { inact }}\right) / k\right)\right)$, where $I / I_{\max }$ is the normalized maximum current, $V_{\mathrm{m}}$ is the conditioning prepulse, $V_{1 / 2 \text { inact }}$ is the voltage for half-inactivation, and $k$ is a slope factor.

Western blot analysis. Total protein extracts from HEK293 cells were obtained using $200 \mu \mathrm{l}$ of lysis buffer (50 mm Tris-HCl, pH 8.0; $150 \mathrm{~mm}$ $\mathrm{NaCl}$; $0.5 \mathrm{~mm}$ PMSF; $1 \%$ Triton X-100; and $1 \times$ protease inhibitor mix (Roche Applied Science). After centrifugation, supernatants were collected for protein quantification by the Bradford assay (Bio-Rad). Aliquots of $60 \mu \mathrm{g}$ of total protein extracts were boiled in SDS sample buffer (50 mu Tris-HCl, pH 6.8; 2\% SDS; $10 \%$ glycerol; $0.1 \%$ 2-mercaptoethanol; $0.001 \%$ bromophenol blue), electrophoresed on $8 \%$ SDS-polyacrylamide gels, and transferred to nitrocellulose membranes. After blocking with nonfat milk (5\%) supplemented with $0.2 \%$ Tween 20 , membranes were incubated for $1 \mathrm{~h}$ with the primary antibodies anti-Ca 3.2 , antiCdk5, or anti-p35 (H-300, catalog \#sc-25691; C-8, catalog \#sc-173; and C-19, catalog \#sc-820; respectively. Santa Cruz Biotechnology) at 1:1000 dilution in TBS-T with 5\% nonfat milk, washed with TBS-T $(10 \mathrm{~mm}$ Tris- $\mathrm{HCl}, 0.15 \mathrm{M} \mathrm{NaCl}, 0.05 \%$ Tween 20 ), and then incubated with goat anti-rabbit secondary antibody coupled to horseradish peroxidase for $1 \mathrm{~h}$. Immunoblots were developed by using the ECL Western blotting analysis system (GE Healthcare Life Sciences) and were visualized with the Odyssey Fc Imaging System (LI-COR Biosciences). The densitometric quantification was performed using ImageJ software (NIH).

Total protein extracts from animal tissues were obtained as follows. Animals were killed by decapitation, and the DRG L5 and L6 were extracted and placed in $1.5 \mathrm{ml}$ tubes containing lysis buffer $(150 \mathrm{~mm} \mathrm{NaCl}$; $50 \mathrm{~mm}$ Tris- $\mathrm{HCl}, \mathrm{pH} 7.5 ; 1 \%$ SDS; $0.5 \%$ sodium deoxycholate; $0.1 \%$ Triton X-100; 1 mM PMSF; and complete). Next, tissues were homogenized at $4^{\circ} \mathrm{C}$ and kept on ice for $20 \mathrm{~min}$, then centrifuged for $10 \mathrm{~min}$ at $\left.-4^{\circ} \mathrm{C}\right)$ at $14,000 \mathrm{rpm}(16,464 \times \mathrm{g})$. The supernatants containing the proteins were collected for quantification using the Bradford method. Denaturing electrophoresis in $10 \%$ polyacrylamide gels with SDS (i.e., SDS-PAGE) using $60 \mu \mathrm{g}$ of total proteins was then performed. Samples were heated at $95^{\circ} \mathrm{C}$ for $5 \mathrm{~min}$ and loaded onto gels. Subsequently, proteins were transferred to polyvinylidene membranes and blocked with $5 \%$ skimmed milk in PBS-0.05\% Tween 20 (PBST), pH 7.4, for $1-2 \mathrm{~h}$ at 
room temperature. Membranes were then washed with PBST and incubated with the mouse anti-Ca 3.2 (1:500 dilution), anti-Cdk5 (1:5000), anti-p35 (1:1000; Santa Cruz Biotechnology), and anti- $\beta$-actin (1: 10,000 ; GeneTex), and incubated for $16 \mathrm{~h}$ at $4^{\circ} \mathrm{C}$. Secondary horseradish peroxidase-conjugated antibodies (anti-rabbit, 1:10000; or anti-mouse, 1:5000) were used in conjunction with the chemiluminescence detection system. Signals were quantified as the optical density index by using the Image Studio 5.2 software (LI-COR Biosciences). The optical density index of each band was normalized to the optical density index of $\beta$-actin.

Immunoprecipitation. Protein extracts from DRG and transfected cells were solubilized in RIPA buffer ( $25 \mathrm{~mm}$ Tris-HCl, pH 7.6; $150 \mathrm{~mm} \mathrm{NaCl}$; $1 \%$ NP-40; $1 \%$ sodium deoxycholate; $0.1 \%$ SDS; 0.5 mM PMSF; and Complete $1 \times)$. For inputs, $60 \mu \mathrm{g}$ of protein samples were boiled for 5 min in protein-loading buffer (1.7\% SDS; $100 \mathrm{~mm}$ 2-mercaptoethanol; $5 \%$ glycerol; $58 \mathrm{~mm}$ Tris- $\mathrm{Cl}$; and $0.002 \%$ bromophenol blue, $\mathrm{pH} 6.8$ ). Each immunoprecipitation assay was performed with $1 \mathrm{mg}$ of protein and $2.5 \mu \mathrm{g}$ of anti-Cdk5, anti-Ca 3.2 , or irrelevant (as isotype control) antibodies, allowing protein interaction overnight at $4^{\circ} \mathrm{C}$. Next, the complexes were incubated with $20 \mu \mathrm{l}$ of Invitrogen recombinant Protein G Agarose (Thermo Fisher Scientific). Immunoprecipitates were washed with a buffer containing $50 \mathrm{~mm}$ Tris- $\mathrm{HCl}, \mathrm{pH} 8,150 \mathrm{~mm} \mathrm{NaCl}, 1 \mathrm{~mm}$ EDTA, 1\% Triton X-100, 10\% SDS, and $100 \mathrm{~mm}$ PMSF, followed by two PBS washes. Protein complexes were eluted in $30 \mu \mathrm{l}$ of protein-loading buffer, resolved by $8 \%$ SDS-PAGE, and then immunoblotted with the anti-Ca 3 3.2, anti-Cdk5, or anti-phosphoserine antibodies (catalog \#p5747, Sigma-Aldrich).

Transient transfection. HEK293 cells (catalog \#CRL-1573, ATCC) were maintained in DMEM-HG cell culture medium, as mentioned previously. Gene transfer was performed using Invitrogen Lipofectamine Plus Reagent (Thermo Fisher Scientific). Briefly, for a $35 \mathrm{~mm}$ Petri dish, 1.6 $\mu \mathrm{g}$ of the plasmid cDNA encoding the human T-type $\mathrm{Ca}^{2+}$ channel $\mathrm{Ca}_{\mathrm{V}} 3.2 \alpha_{1}$ subunit (GenBank accession \#AF051946; Perez-Reyes et al., 1998 ), or its S561A or S1987A mutants, were premixed with $9 \mu \mathrm{l}$ of Lipofectamine in $100 \mu \mathrm{l}$ of serum-free medium, according to the manufacturer instructions, in the presence or absence of $1.5 \mu \mathrm{g}$ of Cdk5 (NM_007668.3) and $0.5 \mu \mathrm{g}$ of p35 (U89527.1) plasmid constructs.

Site-directed mutagenesis. Multiple nucleotide sequences were aligned using the modified Clustal W algorithm of the Invitrogen Vector NTI 8 software package (Thermo Fisher Scientific). Phosphorylation site prediction was performed using the GPS 3.0 software (Group-based Prediction System, version 3.0), a state-of-the-art web-based software for prediction of phosphorylation (available at http://gps.biocuckoo.org/). The $\mathrm{Ca}_{\mathrm{V}} 3.2 \mathrm{cDNA}$ was cloned into the expression plasmid pcDNA3 and expressed under the control of the cytomegalovirus promoter. Two individual point mutations (S561A and S1987A) were introduced with $\sim 40$-mer synthetic oligonucleotides using the Quick-Change XLmutagenesis kit (Stratagene). A third mutant included the mutation of both serine residues (S561 and S1987). All cDNA constructs were sequenced (PerkinElmer/Thermo Fisher Scientific).

Plasma membrane protein extraction. HEK293 cells stably expressing $\mathrm{Ca}_{\mathrm{V}} 3.2$ channels were transfected or not (control) with the cDNA encoding the Cdk5/p35 complex. After $48 \mathrm{~h}$, the extraction of membrane proteins was performed using the Membrane Protein Extraction Kit (catalog \#K268, BioVision) according to the manufacturer instructions. Briefly, cells were grown in $100 \mathrm{~mm}$ culture dishes and collected by centrifugation $(700 \times g$, for $5 \mathrm{~min}$ ), washed with cold PBS, resuspended, and homogenized. The homogenates were centrifuged at $700 \times g$ for $10 \mathrm{~min}$. Pellets containing the cell membrane proteins were mixed with $200 \mu \mathrm{l}$ of the upper and lower phase solutions and centrifuged at $1000 \times g$ for 5 $\mathrm{min}$. The upper phase was transferred to a new tube, diluted in 5 volumes of double-distilled water, and centrifuged for $30 \mathrm{~min}$. Supernatants were removed, and the pellets containing the membrane proteins were dissolved in $0.5 \%$ Triton X-100 in PBS. Proteins were then quantified using the Bradford method, separated by SDS-PAGE gel electrophoresis, and transferred to nitrocellulose membranes. For $\mathrm{Ca}_{\mathrm{V}} 3.2$ channel detection, the membranes were incubated with the anti-Ca 3.2 antibody (Santa Cruz Biotechnology), and the loading control protein was detected with an anti-Cadherin antibody (1:15,000 dilution; Thermo Fisher Scientific).
The quantification of the $\mathrm{Ca}_{\mathrm{V}} 3.2$ signal was normalized to Cadherin and expressed as arbitrary units.

Induction and evaluation of mechanical allodynia. Behavioral tests were performed using male Wistar rats $(150-170 \mathrm{~g})$. Animals were maintained with free access to food and water, in a controlled environment at $22^{\circ} \mathrm{C}$ and under a $12 \mathrm{~h} \mathrm{light/dark} \mathrm{cycle.} \mathrm{All} \mathrm{experiments} \mathrm{were} \mathrm{performed} \mathrm{in}$ accordance with the guide on ethical guidelines for investigations of experimental pain in conscious animals (Zimmermann, 1983). In addition, all studies were approved by the Institutional Animal Care and Use Committee (Protocol 0198-16, Centre for Research and Advanced Studies, Mexico City, Mexico) and complied with the Official Mexican Standard (NOM-062-ZOO-1999).

Animals were anesthetized by intraperitoneal injection of a mixture of ketamine $(50 \mathrm{mg} / \mathrm{kg})$ and xylazine $(10 \mathrm{mg} / \mathrm{kg})$. After surgical preparation, the left spinal nerves L5 and L6 were exposed by removing the paraspinal muscles and ligated with a $6-0$ silk suture in a region distal to the DRG (Kim and Chung, 1992). In the case of the sham-operated rats, the nerves were exposed but not ligated. To determine the presence of mechanical allodynia, the animals were kept in acrylic cages and allowed to habituate for $1 \mathrm{~h}$, and subsequently von Frey filaments (Stoelting) were used to determine the threshold of removal (50\% paw withdrawal threshold) of the hindlimb using the up-and-down method (Chaplan et al., 1994). On days 11-14 after surgery, animals are evaluated again with the von Frey filaments to corroborate the presence of mechanical allodynia. Briefly, the tests started with a filament of $2 \mathrm{~g}$, in the middle of a series of 20 filaments with different rigidity or hardness, which was changed according to the response of the animal. The $50 \%$ withdrawal threshold was determined according to the following formula: $50 \%$ threshold $(g)=\left(10^{\wedge}[X f+k \delta]\right) / 10,000$, where $X f$ is the value of the last von Frey filament used (in logarithmic units); $k$ is the correction factor based on the response patterns of a calibration table and the tabulated value based on the pattern of positive and negative responses; and $\delta$ denotes the average differences between stimuli in logarithmic units (Chaplan et al., 1994). The presence of allodynia is considered when the $50 \%$ withdrawal threshold of the limb is $<4 \mathrm{~g}$.

Intrathecal drug administration. Anesthetized animals were held securely with one hand on the iliac crests while a 25 gauge needle was inserted between the lumbar spinous processes 4 and 5 (Mestre et al., 1994). The needle enters the subarachnoid region perpendicularly producing an involuntary movement of the tail indicative of the appropriate insertion. Before the behavioral evaluation, animals were allowed to recover from anesthesia. Next, the Cdk5 inhibitor olomoucine $(100 \mu \mathrm{M})$ was administered intrathecally to a group of rats. Another group of animals was given $0.025 \%$ DMSO as a control. This evaluation and administration protocol was performed on days 12,13, and 14 after spinal nerve ligation (SNL).

In vitro recordings of cAPs. The spinal nerve-DRG-dorsal root (SNDRG-DR) preparations were obtained from control (sham) and SNL rats $14 \mathrm{~d}$ after surgery. Animals were anesthetized and subjected to a laminectomy that allowed dissection and extraction of the DRG in continuity with the spinal nerves and the dorsal roots. Tissues were collected in Hartmann solution containing the following (in mM): $117 \mathrm{NaCl}, 3.6$ $\mathrm{KCl}, 2.5 \mathrm{NaHCO}_{2}, 1.2 \mathrm{MgCl}_{2}, 25 \mathrm{C}_{6} \mathrm{H}_{12} \mathrm{O}_{6}$, and $1 \mathrm{CaCl}_{2}$ bubbled continuously with mixed gas consisting of $95 \% \mathrm{O}_{2}$ and $5 \% \mathrm{CO}_{2}$. The recordings of the cAPs were obtained at room temperature $\left(\sim 22^{\circ} \mathrm{C}\right)$ by placing the SN-DRG-DR preparation into a recording chamber as follows. The distal end of the spinal nerve was suctioned with a glass electrode connected to an electrical stimulator of rectangular pulses, while the proximal end of the dorsal root was suctioned with a glass electrode connected to an AC amplifier. cAPs were evoked by stimulation of the distal end of the spinal nerves with 300- $\mu$ s-duration current pulses and recorded at the central end with a gain $\times 1000$ with DC-3 kHz filters. One hundred millisecond traces were digitized with a Digidata interface (Molecular Devices) at 50 $\mathrm{kHz}$ and stored in the hard disk of a computer for analysis. The cAPs threshold ( $\mathrm{T}$ ) was determined as the necessary current to evoke a cAP with an occurrence of $50 \%$. Once the cAP recordings evoked at $1.5 \times \mathrm{T}$ were stable, we proceeded to stimulate at intensities of $1.5,3,10,30$, and $50 \times \mathrm{T}$ to obtain the cAPs from distinct primary afferent fibers. To obtain cAPs from synchronized $C$ fibers a total length of $\sim 12 \mathrm{~mm}$ was selected, 
Table 1. Statistical analysis

\begin{tabular}{|c|c|c|c|c|c|}
\hline Data structure & Test & $t$ or $F$ values & $n$ & $p$ Value & Figure \\
\hline Normal $^{*}$ & Student's $t$ test & 2.419 & $4(\mathrm{WB})^{* *}$ & 0.052 & $1 C$ \\
\hline Normal* & Student's $t$ test & 4.259 & $4(W B)^{* * *}$ & 0.005 & 10 \\
\hline Normal $^{*}$ & Student's $t$ test & 0.132 & $6(W B)^{* *}$ & 0.898 & $3 D$ \\
\hline Normal $^{*}$ & Student's $t$ test & 4.123 & $6(\mathrm{WB})^{* *}$ & 0.002 & $3 E$ \\
\hline Normal* & ANOVA (Bonferroni) & 24.898 & $3(\mathrm{WB})^{* *}$ & 0.001 & $4 C$ \\
\hline Normal* & Student's $t$ test & 219 & 13 (cells) & 0.027 & $5 D$ \\
\hline Normal $^{*}$ & Student's $t$ test & 2.971 & $3(\mathrm{WB})^{* *}$ & 0.097 & $6 A$ \\
\hline Normal* & ANOVA (Bonferroni) & 14 & $3(\mathrm{WB})^{* *}$ & $\begin{array}{l}0.012 \text { (SN vs SN) } \\
0.002 \text { (DRG vs DRG) }\end{array}$ & $6 B$ \\
\hline Normal $^{*}$ & Student's $t$ test & 22.85 & $3(\mathrm{WB})^{* *}$ & 0.001 & $7 A$ \\
\hline Normal* & ANOVA (Bonferroni) & 8.3 & $3(\mathrm{WB})^{* * *}$ & 0.040 (DRG vs DRG) & $7 B$ \\
\hline Normal* & Student's $t$ test & 12.89 & $3(\mathrm{WB})^{* *}$ & 0.049 & $8 A$ (left) \\
\hline Normal $^{*}$ & Student's $t$ test & 2.404 & $4(\mathrm{WB})^{* *}$ & 0.095 & $8 A$ (right) \\
\hline Normal $^{*}$ & ANOVA (Bonferroni) & & & 0.002 (SN vs SN) & \\
\hline & & 22 & $3(\mathrm{WB})^{* *}$ & $\begin{array}{l}0.027 \text { (DRG vs DRG) } \\
0.029 \text { (DR vs DR) }\end{array}$ & $8 B$ \\
\hline Normal $^{*}$ & ANOVA (Bonferroni) & $\begin{array}{l}5.8 \\
\text { Day } 0=0.96 \\
\text { Day } 1=23.23\end{array}$ & $3(\mathrm{WB})^{* *}$ & $\begin{array}{l}0.004 \text { (DRG vs DRG) } \\
1.634 \mathrm{e}-9 \text { (sham vs IL; day 1) } \\
1.717 \mathrm{e}-8 \text { (day 3) }\end{array}$ & $8 C$ \\
\hline Normal $^{*}$ & ANOVA (Bonferroni) & $\begin{array}{l}\text { Day } 3=19.69 \\
\text { Day } 7=24.18 \\
\text { Day } 14=35.15\end{array}$ & 6 (experiments) & $\begin{array}{l}\text { 7.071e-10 (day 7) } \\
\text { 8.292e-16 (day 14) } \\
7.998 \mathrm{e}-4 \text { (sham vs CL; day 14) }\end{array}$ & $9 A$ \\
\hline Non-normal ${ }^{*}$ & Kruskal-Wallis & 286.069 & 180 (traces) & $2.596 \mathrm{e}-137$ & $9 E$ \\
\hline Non-normal* ${ }^{*}$ & Kruskal-Wallis & 275.999 & 210 (traces) & $\begin{array}{l}7.642 \mathrm{e}-63 \\
2.084 \mathrm{e}-10 \text { (sham vs SNL) } \\
1.867 \mathrm{e}-10 \text { (sham vs DMSO) }\end{array}$ & $9 F$ \\
\hline Normal $^{*}$ & ANOVA (Bonferroni) & 53.613 & $\begin{array}{l}\text { 6-11 } \\
\quad \text { (experiments) }\end{array}$ & $\begin{array}{l}0.036 \text { (sham vs Olo) } \\
1.157 \mathrm{e}-7 \text { (SLN vs Olo) } \\
1.426 \mathrm{e}-7 \text { (DMSO vs 0lo) }\end{array}$ & $10 B$ \\
\hline Non-normal* & Kruskal-Wallis & 166.1११ & 120 (traces) & $\begin{array}{l}\text { 2.186e-44 (Ctl vs Sham) } \\
1.625 \mathrm{e}-27 \text { (Ctl vs SNL) }\end{array}$ & $10 C$ \\
\hline Non-normal* & Kruskal-Wallis & 216.7११ & 120 (traces) & $\begin{array}{l}\text { 5.437e-26 (Ctl vs Mib) } \\
\text { 9.087e-48 (Ctl vs Mib + 0lo) }\end{array}$ & $10 E$ \\
\hline
\end{tabular}

WB, Western blot; IL, ipsilateral; $\mathrm{CL}$, contralateral; $\mathrm{Ctl}$, control; Mib, mibefradil; Olo, olomoucine.

*Data normality was initially determined using the Kolmogorov-Smirnov test; ${ }^{* *}$ Values derived from $n$ separate experiments, each performed in triplicate. १, $\chi^{2}$; $\uparrow \uparrow$, Dunn's post hoc test.

which included the spinal nerve, the DRG, and the dorsal root. For each stimulation intensity, 30 traces were recorded at a frequency of $0.2 \mathrm{~Hz}$ in the absence or the presence of olomoucine $(100 \mu \mathrm{M})$ and/or mibefradil (500 nM).

Statistical analysis. All data are presented as the mean \pm SEM. Data normality was initially determined using the Kolmogorov-Smirnov test. When data were normally distributed, the statistical significance of differences between two sets of averaged data was established according to the Student's $t$ test. Likewise, ANOVA was also performed for multiple comparisons and Bonferroni's post hoc test was used for pairwise comparisons (Table 1). Experiments using antibodies were performed at least in triplicate; $n$ refers to the number of animals or cells under each condition. Statistical significance is indicated by an asterisk. When data were not normally distributed, the statistical significance of differences was assessed using Kruskal-Wallis analyses followed by Dunn's post hoc tests for pairwise comparisons (Table 1). Statistical analysis was performed using SigmaPlot (version 12.3, SYSTAT) and GraphPad Prism version 7 (GraphPad Software).

\section{Results}

\section{Upregulation of $\mathrm{Ca}_{\mathrm{v}} 3.2$ current by $\mathrm{Cdk} 5 / \mathrm{p} 35$ transfection}

We first evaluated the functional consequences of the Cdk5/p35 complex on the activity of T-type $\mathrm{Ca}_{\mathrm{V}} 3.2$ channels, by whole-cell patch-clamp recordings performed in HEK293 cells stably expressing the channels, after transient transfection of Cdk5/p35. As shown in Figure $1 A$, current density through $\mathrm{Ca}_{\mathrm{V}} 3.2$ channels was significantly increased in the voltage range of -50 to $0 \mathrm{mV}$, in the presence of the Cdk5/p35 complex components, compared with the control condition. Likewise, the presence of the Cdk5 inhibitor, olomoucine (100 $\mu \mathrm{M} ; 48 \mathrm{~h})$, prevented the stimulatory effect of the kinase on the $\mathrm{Ca}_{\mathrm{V}} 3.2$ current density. This is consistent with our previous observation that the silencing of $\mathrm{Cdk} 5$ using specific siRNAs abrogates the effect of the kinase on the $\mathrm{Ca}_{\mathrm{V}} 3.1$ channels heterologously expressed in HEK293 cells (Calderón-Rivera et al., 2015). To investigate whether the Cdk5/ p35 complex effect on the $\mathrm{Ca}_{\mathrm{V}} 3.2$ channels was mediated by alterations in channel gating, the voltage dependence of the currents was assessed next. A normalized conductance-voltage relationship was then generated for the control (GFP transfected) and Cdk5/p35-transfected cells (Fig. $1 B$ ). The results show that the half-maximal activation voltage $\left(V^{1 / 2}\right)$ in the control cells was approximately $-44 \mathrm{mV}$, which did not differ significantly from that of the Cdk5/p35-transfected cells (approximately $-47 \mathrm{mV}$ ). The slope factors $(k)$ for the Boltzmann fits were also similar.

Likewise, the properties of current inactivation at steady state were determined using $1 \mathrm{~s}$ conditioning prepulses ranging from -110 to $-20 \mathrm{mV}$ in $10 \mathrm{mV}$ voltage steps, followed by a $140 \mathrm{~ms}$ step depolarization to $-30 \mathrm{mV}$. The normalized current amplitudes were plotted against its corresponding potential and fitted with Boltzmann equations. The results show that the voltage dependence of inactivation was similar in the currents recorded from control cells and cells expressing Cdk5/p35 (Fig. 1B). For control cells, the $V_{1 / 2}$ was $-71 \mathrm{mV}$, which did not differ significantly from that of Cdk5/p35-transfected cells $(-67.5 \mathrm{mV})$. Given that the slope factors were also unaffected, it is concluded that the presence of the kinase and its activator augment the 
A

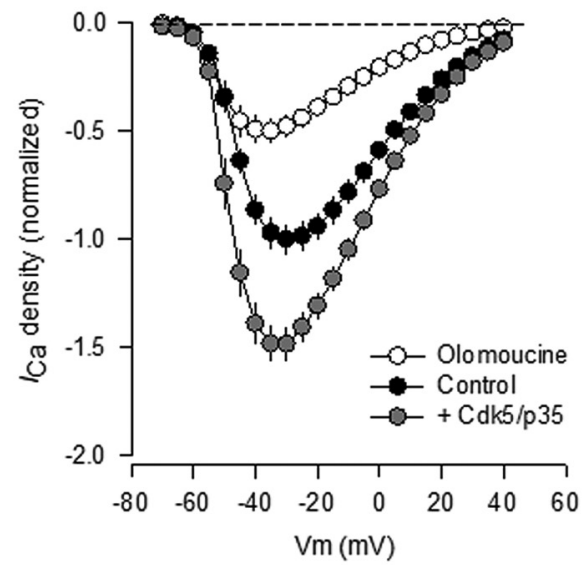

B

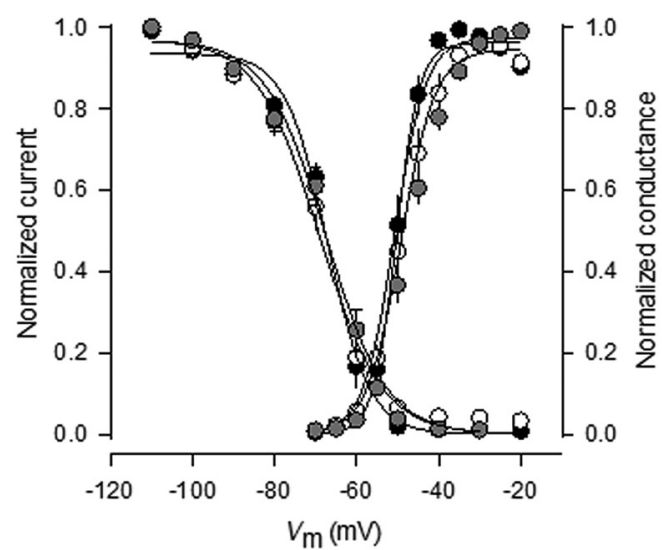

C
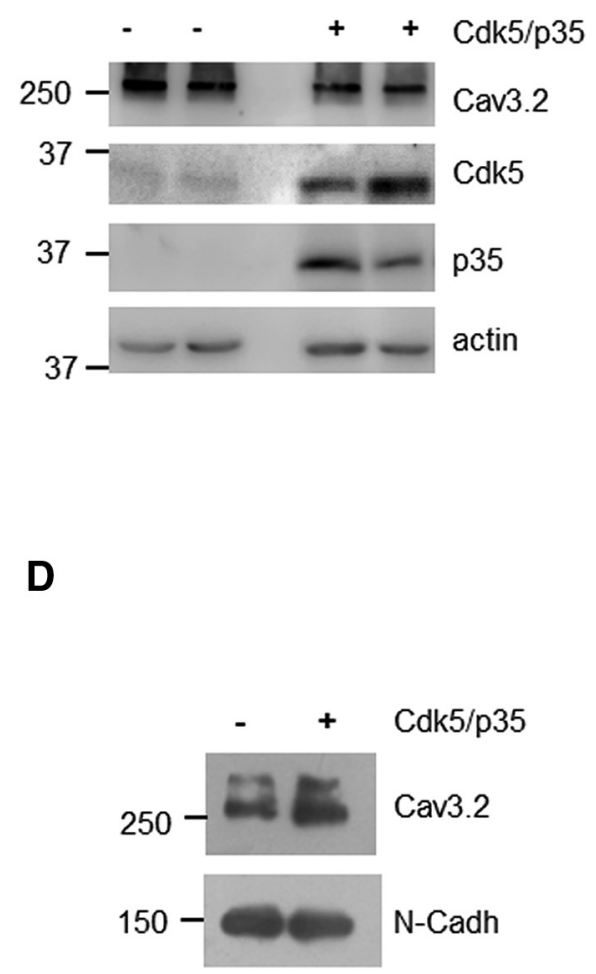

D
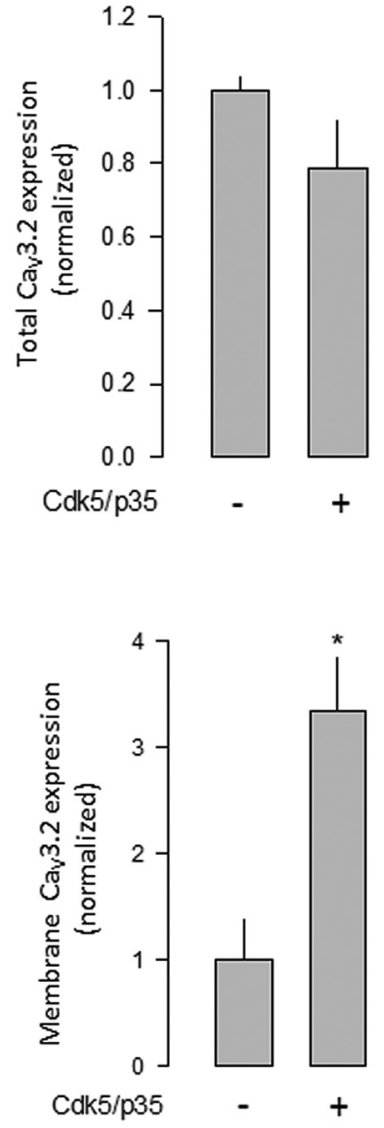

Figure 1. The cotransfection of $\left(\mathrm{dk} 5\right.$ and $\mathrm{p} 35$ regulates the expression of recombinant $\mathrm{Ca}_{\mathrm{v}} 3.2$ channels in HEK293 cells. $\boldsymbol{A}$, Averaged and normalized $\left(\mathrm{a}_{2+}\right.$ current $\left(I_{\mathrm{Ca}}\right)$-voltage relationships in HEK293 cells stably expressing C $\mathrm{a}_{\mathrm{v}} 3.2$ channels in the control condition or after transient transfection of the Cdk5/p35 complex, as well as after treatment with the kinase inhibitor olomoucine (100 $\mu \mathrm{m}$ ) for $48 \mathrm{~h}$ ( $n=18-35$ recorded cells). $\boldsymbol{B}$, Comparison of steady-state inactivation and activation curves for Ca 3.2 channels as in $\boldsymbol{A}(n=15-26)$. Curves were fitted with Boltzmann equations. A two-pulse protocol was used to estimate the voltage dependence of inactivation. The channel activation curve was estimated by measuring peak current during different test steps from a $V_{\mathrm{h}}$ value of $-80 \mathrm{mV}$. The current value at each potential was divided by the driving force for $\mathrm{Ca}^{2+}$ ions. C, Western blot analysis showing the expression of $\mathrm{Ca}_{\mathrm{v}} 3.2$, $\mathrm{Cdk}^{2}$, and p35 in total lysates from HEK293 cells in the presence and absence of Cdk5/p35, as indicated (left). $\beta$-actin was used as a loading control. Right, The bar chart summarizes the results of four independent experiments. The differences observed were not statistically significant according to the Student's $t$ test (Table 1). In addition, the power of the performed test (0.252) was below the desired power of 0.800 . $\boldsymbol{D}$, Western blot of HEK293 membrane protein lysates obtained with anti-Ca 3.2 antibodies in the presence and the absence of (dk5/p35, as indicated (right). The apparent molecular size markers are shown on the left. $\mathrm{N}$-Cadherin ( $\mathrm{N}$-Cadh) was used as the loading control. The bar chart on the right summarizes the results of four independent experiments, and the asterisk denotes a significant difference from the control condition (Table 1).

density of the $\mathrm{Ca}_{\mathrm{V}} 3.2$ channel currents with no significant effects on the gating of the channels.

\section{Cdk5/p35 transfection increases the membrane expression of recombinant $\mathrm{Ca}_{\mathrm{v}} 3.2$ channels}

To investigate whether the current density increase observed in the functional studies was related to an augmentation in $\mathrm{Ca}_{\mathrm{V}} 3.2$ protein expression, we analyzed the total protein expression in whole-cell lysates obtained from HEK 293 cells. The components of the Cdk5/p35 complex were transfected in the HEK293 cells stably expressing $\mathrm{Ca}_{\mathrm{V}} 3.2$ channels, and the relative expression of the channel protein was determined by Western blotting. To this end, specific anti-Ca $\mathrm{Ca}_{\mathrm{V}} 3.2$ antibodies were used, and the channel signal was compared with the loading controls using anti-actin antibodies (Fig. 1C). The $\mathrm{Ca}_{\mathrm{V}} 3.2$ channel protein appeared as a $>250 \mathrm{kDa}$ band whose expression was slightly decreased, in the presence of Cdk5/p35 (Fig. 1C, right). The differences observed were not statistically significant (Table 1 ), and the power of the statistical test performed was below the desired value. This result suggests that the increase in current density after Cdk5/p35 expression may not be attributable to higher levels of total channel protein expression. It is worth mentioning that in untransfected HEK293 cells we found a $\sim 35 \mathrm{kDa}$ protein band using the antiCdk5 antibody, suggesting that Cdk5 is endogenously expressed in this cell line (Fig. 1C, left).

The previous electrophysiological results suggested that the upregulation of the current caused by Cdk5/p35 could be related to an increase in the number of channels located at the plasma membrane. To test this, we next performed experiments in which plasma membrane proteins were isolated from cells stably expressing the $\mathrm{Ca}_{\mathrm{V}} 3.2$ channel alone or transfected with the Cdk5/ p35 complex. As shown in Figure $1 D$, the densitometric analysis showed that the expression of $\mathrm{Cdk} 5 / \mathrm{p} 35$ resulted in higher levels of the $\mathrm{Ca}_{\mathrm{V}} 3.2$ channel protein at the plasma membrane fraction compared with the control condition. Together, these data suggest that the Cdk5/p35 complex may play a relevant role in favoring the localization of the channels at the cell membrane, without changing significantly their total expression. 
A

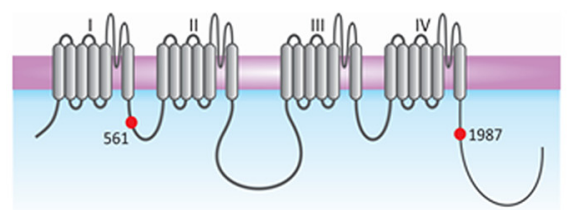

B

S561

Cacnalh human (554) GAPPSPP PPRPPPD Cacnalh mouse (555) CVPPSPP 5 PGH $: P P D$ Cacnalh rat (555) CAPPSPP 5 PGH $: P P D$

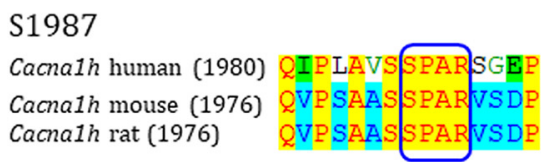

C
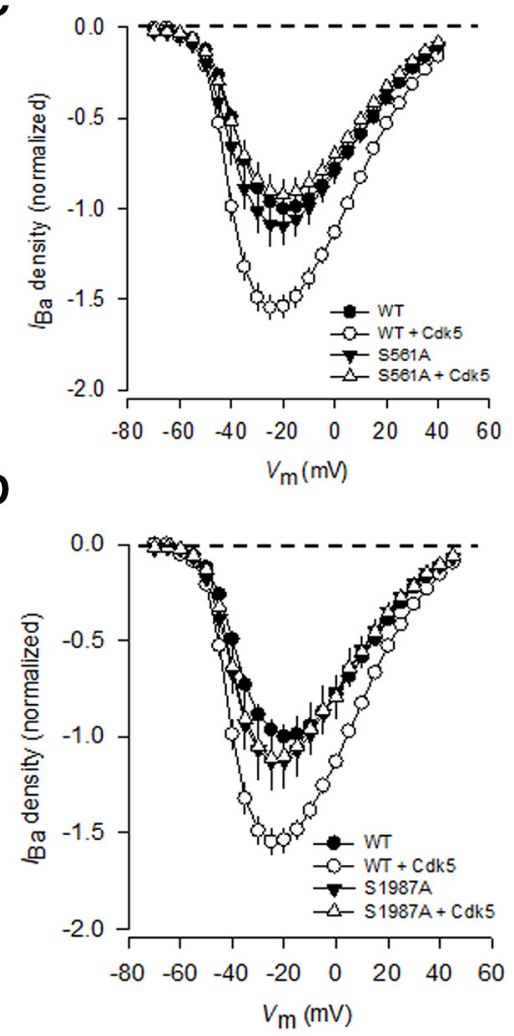
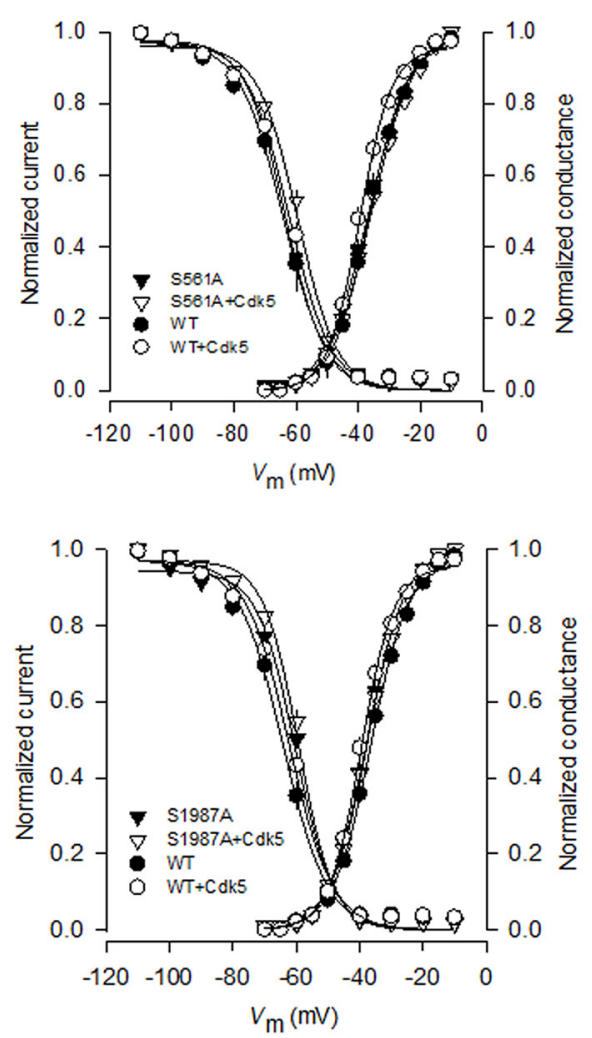

Figure 2. The S561A and S1987A mutations prevent the Cdk5/p35-mediated regulation on Ca 3.2 channel activity. $A$, The $C a_{v} 3.2 \alpha_{1}$ subunit is a monomer consisting of four homologous repeated domains (I-IV) with six transmembrane segments (S1-S6). The S4 in each repeated domain has positively charged amino acids and represents the voltage sensor. The pore region is defined by the loop between $\mathrm{S} 5$ and $\mathrm{S} 6$. The mutations generated in this study are denoted as small red circles. $\boldsymbol{B}$, Sequence alignment of regions in the $\mathrm{Ca}_{\mathrm{v}} 3.2 \alpha_{1}$ protein from distinct species showing the consensus phosphorylation site for Cdk5. C, Average normalized Ba ${ }^{2+}$ current $\left(I_{B a}\right)$ densities as a function of voltage (I-V curves) in HEK293 cells transiently expressing the wild-type or the S561A mutant $\mathrm{Ca}_{\mathrm{v}} 3.2 \alpha_{1}$ subunits obtained in the presence or absence of $\mathrm{Cdk} 5$ (left). Right, Comparison of the corresponding average normalized activation and steady-state inactivation curves $(n=11-35)$. $\boldsymbol{D}$, Average normalized I-V curves in HEK293 cells expressing the wild-type or the S1987A mutant Ca $3.2 \alpha$, subunits obtained in the presence or absence of Cdk5. Right, Corresponding average normalized activation and steady-state inactivation curves $(n=11-35)$.

\section{S561 and S1987 mutation prevents the Cdk5/p35-mediated regulation of the channels}

Recently, multiple phosphorylatable residues for the human $\mathrm{Ca}_{\mathrm{v}} 3.2$ channel have been reported (Blesneac et al., 2015). However, for most of these phosphorylation sites, the kinase or their functional effects have not been described. Given that Cdk5 is able to regulate the currents through $\mathrm{Ca}_{\mathrm{V}} 3.2$ channels, we searched for possible amino acids in the $\mathrm{Ca}_{\mathrm{V}} 3.2$ protein that could be phosphorylatable by the kinase. Initial in silico analysis of the human $\mathrm{Ca}_{\mathrm{V}} 3.2$ channel using a computational prediction software (available at http://gps.biocuckoo.org/online.php), showed 15 potential phosphorylation sites for Cdk5. The consensus sequence of phosphorylation by Cdk 5 has been reported to be $\mathrm{S}$ or $\mathrm{T} / \mathrm{P} / \mathrm{X} /(\mathrm{H}, \mathrm{R}$ or $\mathrm{K})$ : in the first position the serine or threonine target to be phosphorylated $(\mathrm{p})$, followed by a proline, any amino acid in the third position and finally a histidine, arginine, or lysine residue. According to this, our search was reduced to only two serine candidates located at positions 561 and 1987, which coincidentally had the highest scores and were conserved among human, rat, and mouse (Figs. 2A,B). Therefore, these amino acid residues were selected for further mutagenesis analyses.

We first mutated S561 and S1987 residues individually to alanine, and the mutant channels were heterologously expressed in HEK293 cells and analyzed by patch-clamp electrophysiology. As previously shown, the transient transfection of Cdk5/p35 increased the wild-type $\mathrm{Ca}_{\mathrm{V}} 3.2$ channel current density, without affecting the activation or inactivation properties of the channels.
In sharp contrast, the presence of the mutations prevented the upregulation of the currents caused by Cdk5/p35 (Figs. 2C,D, left panels). The activation and inactivation curves were also similar in both conditions (Fig. 2C,D, right panels). These results support the idea that the serine residues at positions 561 and 1987 in $\mathrm{Ca}_{\mathrm{V}} 3.2$ are required for the $\mathrm{Cdk} 5 / \mathrm{p} 35$-mediated regulation.

The effect of Cdk5/p35 on $\mathrm{Ca}_{\mathrm{V}} 3.2$ channels bearing an $\mathrm{S} 561 \mathrm{~A} /$ S1987A double mutation was then investigated. To this end, we first performed whole-cell patch-clamp experiments on HEK293 cells expressing the wild-type $\mathrm{Ca}_{\mathrm{V}} 3.2$ channels and the double mutant. Figure $3 A$ compares the amplitude of the currents elicited by a depolarization step from a holding potential $\left(V_{\mathrm{h}}\right)$ of -80 $\mathrm{mV}$ to a test potential of $-30 \mathrm{mV}$ obtained in the presence and the absence of Cdk5/p35. The amplitude of the currents through wild-type channels was increased after Cdk5/p35 coexpression. In comparison, no modification of the currents through channels harboring the double mutation was observed in the presence of the kinase and its activator (Fig. $3 A$ ). In consequence, the current density-voltage relationships obtained in the absence of Cdk5/ p35 were similar to those observed in the wild-type channel currents but, as expected, the transient transfection of the Cdk5/p35 complex did not stimulate the current as observed for the wildtype channels (Fig. 3B). The voltage dependence of activation and inactivation remained unchanged, as occurred with the single S561A and S1987A mutations (Fig. 3C).

We next sought to determine whether the loss of the Cdk5/ p35-mediated functional regulation in the S561A/S1987A mu- 
A

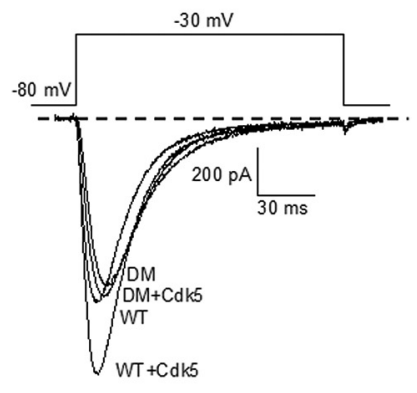

D
B

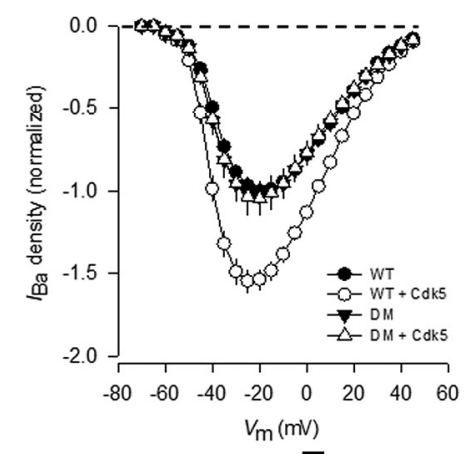

C

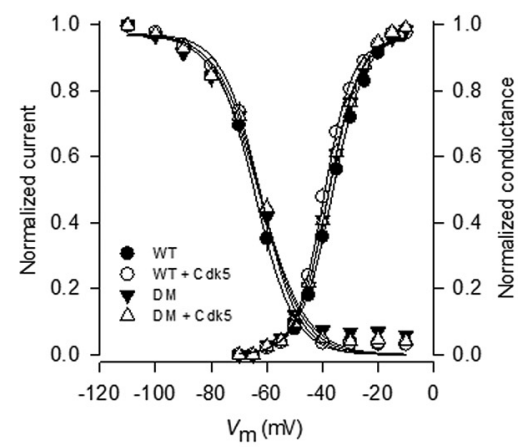

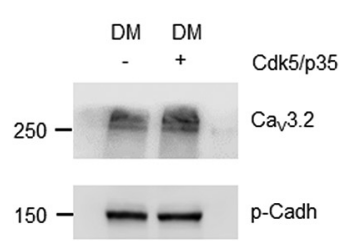

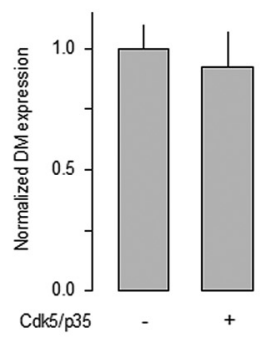

E

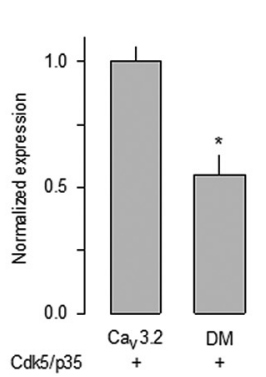

Figure 3. The double $5561 \mathrm{~A} / \mathrm{S} 1987 \mathrm{~A}$ mutant is insensitive to the $\mathrm{Cdk5} / \mathrm{p} 35$-mediated regulation. $A$, Representative superimposed Ba ${ }^{2+}$ current $\left(I_{\mathrm{Ba}}\right)$ traces recorded in $\mathrm{HEK} 293$ cells transiently transfected the wild-type or the double mutant (S561A/S1987A; DM) Cav $3.2 \alpha_{1}$ subunits. Currents were evoked by applying voltage steps to $-30 \mathrm{mV}$ from a $V_{\mathrm{h}}$ of $-80 \mathrm{mV}$. B, Average normalized I-V curves in HEK293 cells expressing the wild-type or the $\mathrm{Ca}_{\mathbf{\gamma}} 3.2 \alpha_{1}$ DM subunits obtained in the presence or absence of $\mathrm{Cdk} 5$ as in $\boldsymbol{A}(n=18-35$ recorded cells). $C$, Average normalized activation and steady-state inactivation curves as a function of membrane voltage obtained in transfected cells as in $\boldsymbol{B}(n=18-35)$. Normalized activation and inactivation curves were fit to Boltzmann functions. $\boldsymbol{D}, \boldsymbol{E}, \mathrm{Cdk5} / \mathrm{p} 35$ regulates the levels of $\mathrm{Ca}_{\mathrm{v}} 3.2$ at the plasma membrane but not the $\mathrm{DM}$ mutant channel. $\boldsymbol{D}$, Western blot analysis of the $\mathrm{Ca}_{\mathrm{v}} 3.2 \alpha 1 \mathrm{DM}$ channel protein expression at the membrane in HEK293 cells in the absence or presence of $\mathrm{Cdk5} / \mathrm{p} 35$ were separated by SDS-PAGE, and the bands were normalized to $\mathrm{p}$-Cadherin ( $n=6$ independent experiments). $\boldsymbol{E}$, Immunodetection of the $\mathrm{Ca}_{\mathrm{v}} 3.2 \alpha 1$ WT or DM membrane proteins plus $\mathrm{Cdk} 5 / \mathrm{p} 35$. The signal for the $\mathrm{Ca}_{\mathrm{v}} 3.2$ channel was normalized to $\mathrm{p}$-Cadh, used as loading control, and detected by chemiluminescence, as described in Materials and Methods. The bar charts at the right summarize the results of six independent experiments, and the asterisk denotes a significant difference from the control condition (Table 1).

tant channels was associated with less channel expression at the cell membrane. To this end, the relative expression of the $\mathrm{Ca}_{\mathrm{V}} 3.2$ wild-type and the mutant construct were quantified and normalized to p-Cadherin. Figure 3, $D$ and $E$, shows that the relative expression of the S561A/S1987A mutant channels in cell membrane extracts from transfected HEK293 cells was similar in the absence and the presence of the Cdk5/p35 complex (Fig. 3D, right). However, the proportion of wild-type channels was approximately twofold higher than the S561A/S1987A mutant channels in the presence of Cdk5/p35 (Fig. 3E, right).

The above-described results suggested that Cdk5/p35 modulates the $\mathrm{Ca}_{\mathrm{V}} 3.2$ channels through phosphorylation of serine residues at positions 561 and 1987. Therefore, we next decided to investigate in more detail the interaction between the kinase and the $\mathrm{Ca}_{\mathrm{V}} 3.2$ channels using immunoprecipitation assays. Figure 4 , top, shows that the use of a Cdk5-specific antibody resulted in the immunoprecipitation of a $>250 \mathrm{kDa}$ band, the expected size of the $\mathrm{Ca}_{\mathrm{V}} 3.2$ channel protein (detected using a $\mathrm{Ca}_{\mathrm{V}} 3.2$ antibody). To investigate whether the presence of the S561A and S1987A mutations in the $\mathrm{Ca}_{\mathrm{V}} 3.2$ channel may alter the interaction with Cdk5, we transfected HEK293 cells with the cDNAs encoding the mutant channels and performed the immunoprecipitation assays in the same experimental conditions. Figure $4 A$, middle and bottom, shows that the interaction of the kinase with the $\mathrm{Ca}_{\mathrm{V}} 3.2$ proteins occurs with both the wild-type and the mutant channels, suggesting that the kinase could be interacting with other sites in the channel protein; however, the intensity of the immunosignal was decreased in the presence of the Cdk5 inhibitor olomoucine (Fig. 4A, middle) or the mutations (Fig. $4 A$, bottom). Here it is worth noting that these results show an additive reduction of interaction using the double mutant, but the functional studies show a full effect with only one mutation. The reason for this discrepancy is not presently known, however, it could be related to the fact that the mutation of only one of the serine residues is sufficient to induce a conformational change in the channel protein that abrogates the functional effect of the phosphorylation event. On the other hand, the mutation of two serine residues, in addition to affect the phosphorylation process, could be causing a greater disruption in the physical interaction between the kinase and the channels.

We next studied the phosphorylation of the wild-type channel and its mutants using anti-phosphoserine antibodies in the absence and the presence of olomoucine. Figure $4, B$ and $C$, shows that, in the presence of the $\mathrm{Cdk} 5$ inhibitor or the mutations in the serine residues, the phosphorylation of the channel was significantly decreased.

The interaction between $\mathrm{Cdk} 5$ and the $\mathrm{Ca}_{\mathrm{V}} 3.2$ channels was also observed in immunoprecipitation assays using cell lysates from DRG. As can be seen in Figure $5 A$, the immunoprecipitation assay using an anti-Cdk 5 antibody and the subsequent analysis by Western blot revealed the presence of a $>250 \mathrm{kDa}$ band, the expected size for the $\mathrm{Ca}_{\mathrm{V}} 3.2$ channel protein. On the other hand, the reciprocal experimental maneuver, that is, the immunoprecipitation using an anti-Ca 3.2 antibody and the subsequent analysis by Western blot, resulted in the identification of a band of a $\sim 35 \mathrm{kDa}$, the estimated size of the kinase. We then evaluated the possible functional consequences of the Cdk5/p35-mediated phosphorylation on the $\mathrm{Ca}_{\mathrm{V}}$ channels in the DRG neurons by 
comparing the current densities in the absence and the presence of olomoucine. Figure $5 B$ shows superimposed representative traces of the total currents through $\mathrm{Ca}_{\mathrm{V}}$ channels in DRG neurons in the presence and the absence of the Cdk5 inhibitor. Interestingly, the presence of olomoucine significantly reduced $\mathrm{Ca}_{\mathrm{V}}$ current density in the DRG neurons (Fig. $5 C)$. It is worth recalling that the DRG neurons express both HVA and low voltage-activated (LVA) channels; therefore, we next investigated whether the effects of olomoucine were mediated by its action on the LVA channels (T-type or $\mathrm{Ca}_{\mathrm{V}} 3$ ). To separate the total current into its two components, an standard experimental maneuver was used, which consisted in applying two $100 \mathrm{~ms}$ depolarizing steps to $0 \mathrm{mV}$ from a $V_{\mathrm{h}}$ of $-80 \mathrm{mV}$ separated by a $10 \mathrm{~ms}$ interpulse interval. The two components of the total currents are activated during the first step; however, the LVA channels inactivate at the end of this pulse. As a consequence, the second depolarizing step to $0 \mathrm{mV}$ activates only the HVA component of the current. By subtracting the currents obtained in response to the second pulse from those obtained with the application of the first pulse, the magnitude of the LVA component could be estimated. When comparing the results of this analysis, we found that olomoucine caused a significant decrease (of $\sim 20 \%$ ) in the density of the LVA currents recorded in the DRG neurons, suggesting that the kinase inhibitor was acting by preventing the phosphorylation of the LVA $\left(\mathrm{Ca}_{\mathrm{V}} 3\right)$ channels (Fig. $\left.5 D\right)$.

\section{Effect of the spinal nerve ligation on the expression and localization of Cav3.2}

Given that diverse types of neuronal ion channels, including $\mathrm{Ca}_{\mathrm{V}} 3.2$, are important in the development of neuropathic pain, and that SNL induces mechanical allodynia in animal models, we next investigated the effect of SNL on the expression of the proteins of interest using specific antibodies. First, when studying the expression of the $\mathrm{Ca}_{\mathrm{V}} 3.2$ channel in the DRG of animals in the sham-operated and the SNL group, a band of $>250 \mathrm{kDa}$ was detected, which corresponds to the expected molecular weight of the channel protein (Fig. $6 A, B$ ). In these initial assays, SNL did not induce significant changes in the expression of the $\mathrm{Ca}_{\mathrm{V}} 3.2$ channels $14 \mathrm{~d}$ after nerve ligation (Fig. 6A), which disagrees with recent studies reporting an increase in the expression of these channels after injury or spinal nerve ligation (Shiue et al., 2016; Liu et al., 2019). Nevertheless, it is worth noting here that these results corresponded to what was observed from total cell lysates made from a preparation that included the spinal nerve, the DRG, and the dorsal root (not from the plasma membrane fraction only).

However, when the lysates were obtained from the nerves, the ganglia, or the dorsal roots separately, a differential distribution of the channel proteins was observed (Fig. 6B). In particular, a drastic decrease in $\mathrm{Ca}_{\mathrm{V}} 3.2$ expression was observed in the spinal
B

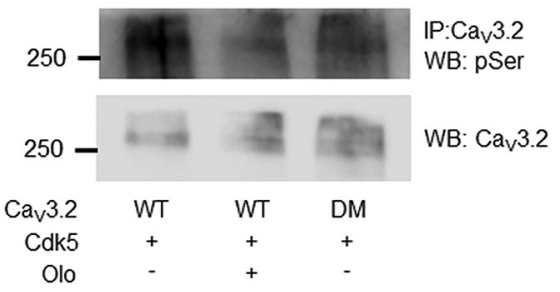

C

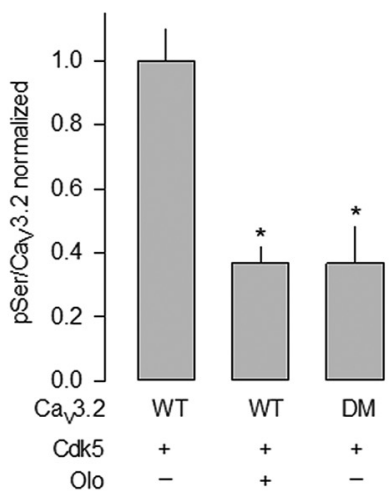

Figure 4. C C dk5 associates with the wild-type Cay 3.2 channel and its mutants in total lysates of HEK293 cells. $\boldsymbol{A}$, Top, Cell lysates immunoprecipitate the channel $\mathrm{Ca}_{\mathrm{v}} 3.2 \alpha$, protein. Middle, Immunoprecipitation of the C $\mathrm{a}_{\mathrm{v}} 3.2$ channels from lysates of HEK293 列 ies, as indicated. $\boldsymbol{C}$, Bar chart summarizing the results of three independent experiments; the asterisk denotes a significant IP: Cdk5 WB: Cav3.2

IP: Cav3.2

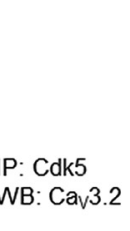

nerves of animals subjected to SNL compared with shamoperated controls, and a significant increase $(\sim 2.5$-fold $)$ in the $\mathrm{Ca}_{\mathrm{V}} 3.2$ expression in the DRG after SNL was also observed. Together, these data suggest that there is an accumulation of $\mathrm{Ca}_{\mathrm{V}} 3.2$ channels in the DRG, as a result of a decrease in the channels in the spinal nerves (Chen et al., 2018; Liu et al., 2019).

Likewise, in the case of Cdk5, an $\sim 33 \mathrm{kDa}$ band was observed in both sham-operated and animals with the nerve ligation. Figure $7 A$ shows that ligation of the spinal nerves L5-L6 increased the expression of the kinase $14 \mathrm{~d}$ after nerve injury compared with what was observed in sham-operated animals. As for $\mathrm{Ca}_{\mathrm{V}} 3.2$, these initial results were obtained from total cell lysates that included the spinal nerves, the DRG, and the dorsal roots. When the lysates were obtained from the different anatomical regions separately, a significant increase in the expression of Cdk5 was observed in the DRG, but no apparent changes were noted in the spinal nerves or the dorsal roots (Fig. $7 B$ ).

In the case of the Cdk5 activators, p35 and p25, bands of $\sim 35$ and $\sim 25 \mathrm{kDa}$ corresponding to the molecular weight of these proteins were detected. Figure $8 A$ shows that nerve injury had a dual regulation on the expression of p35 and p 25 after $14 \mathrm{~d}$ of surgery. Hence, the expression of p 25 increased significantly with respect to the control, while the expression of p35 decreased in parallel. Likewise, Figure $8, B$ and $C$, shows that the expression of p35 and p25 was also affected differentially when the anatomical regions were analyzed separately. While a decrease in the p35 expression was observed in the spinal nerves of animals subjected 
A

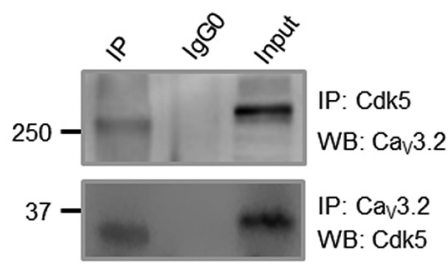

C

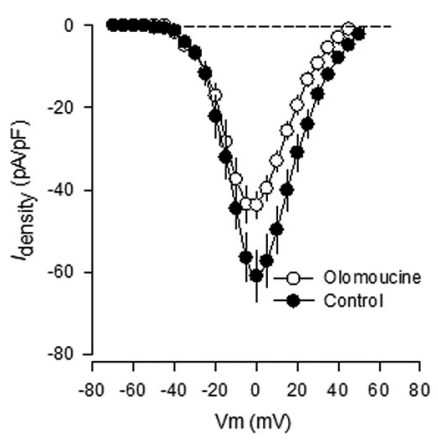

B

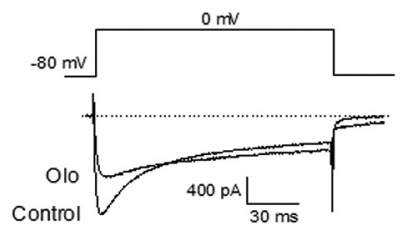

D

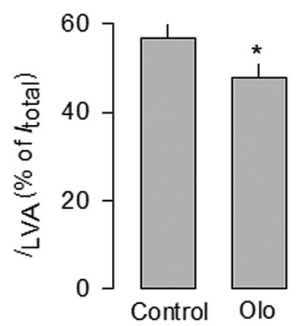

Figure 5. C $\quad \mathrm{dk} 5$ regulates the $\mathrm{Ca}_{\mathrm{V}}$ channel currents in DRG neurons. $A$, Immunoprecipitation of $\mathrm{Ca}_{\mathrm{V}} 3.2$ channels and $C \mathrm{dk} 5$ in the DRG. Top, Western blot (WB) of the immunoprecipitation (IP) of the Ca 3.2 channels using C $\mathrm{dk} 5$ or control (Ig0) antibodies. Bottom, Reciprocal immunoprecipitation experiment for $\mathrm{Cdk} 5$. The results are representative of three independent determinations. $B$, Superimposed current traces recorded in DRG neurons in the absence and the presence of the $C \mathrm{dk} 5$ inhibitor olomoucine. Currents were evoked by applying voltage steps to $0 \mathrm{mV}$ from a $V_{\mathrm{h}}$ of $-80 \mathrm{mV}$. C, Average normalized $I_{\text {density }}-V$ curves in DRG neurons obtained in the presence or absence of olomoucine as in $\boldsymbol{B}(n=13$ recorded cells). For these electrophysiological recordings, only small cells were used (Scroggs and Fox, 1992). The $C_{m}$ values varied from 22.2 to 23.4 pF, and the diameter of the cells ranged from 15.6 to $17.5 \mu \mathrm{m}$ in control and olomoucine-treated cells, respectively. D, Comparison of the isolated LVA (Ca 3 ) channel current component in the presence or absence of olomoucine. The asterisk denotes a significant difference from the control condition (Table 1).

A
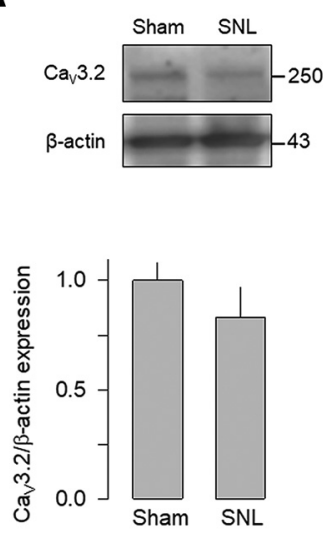

B
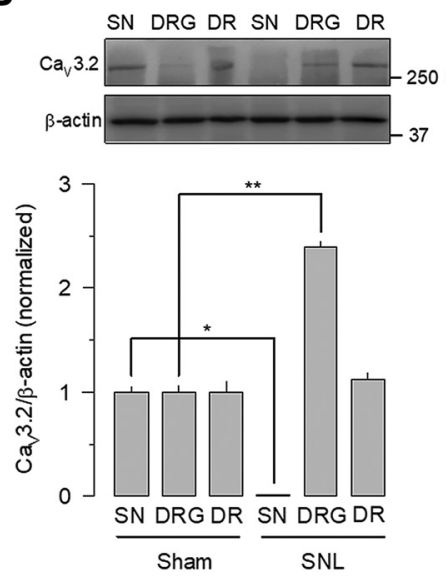

Figure 6. SNL increases the relative expression of $\mathrm{Ca}_{\mathrm{V}} 3.2$ in the DRG. $\boldsymbol{A}$, Top, Comparative Western blot analysis of $\mathrm{Ca}_{\mathrm{v}} 3.2$ protein expression in sham-operated animals and rats with allodynia induced by ligation of the spinal nerves $\mathrm{L} 5-\mathrm{L} 6$. Channel proteins were detected in cell lysates from DRG L5-L6 $14 \mathrm{~d}$ after SNL using anti-Cav3.2 antibodies. Bottom, Corresponding protein band signal intensities of channel proteins normalized to $\beta$-actin levels to obtain the relative expression of the $C_{y} 3.2 \alpha$ subunit. The results are representative of three independent experiments. $\boldsymbol{B}$, Top, Comparative Western blot analysis of $\mathrm{C}_{\mathrm{v}} 3.2$ protein expression in shamoperated animals and rats with mechanical allodynia induced by the ligation of the spinal nerves, in lysates from the spinal nerve $S N$, the DRG, and the DR. Channel proteins were detected in lysates from L5-L6 $14 \mathrm{~d}$ after SNL using anti-Ca 3.2 antibodies. Bottom, Corresponding protein band signal intensities of channel proteins normalized to $\beta$-actin levels to obtain the relative expression of the $\mathrm{Ca}_{\mathrm{v}} 3.2 \alpha_{1}$ subunit. The bar charts summarize the results of at least three independent experiments. Two-way ANOVA was performed for multiple comparisons followed by Bonferroni's tests for pairwise comparisons $\left({ }^{*} p=0.012,{ }^{* *} p=0.002\right.$; Table 1).

to SNL compared with sham-operated controls, a significant increase (of 20\%) in the expression of this Cdk5 activator was observed in the DRG and the dorsal roots after SNL (Fig. $8 B$ ). In the case of p25, a significant increase $(\sim 60 \%)$ was observed in the DRG (Fig. $8 C$ ), and no significant changes were noted in the rest of the regions analyzed.

\section{Effect of the SNL and $\mathrm{Ca}^{2+}$ channel blockers on the cAPs recorded in sensory $\mathrm{C}$ fibers}

Given that the expression of both T-type channels and Cdk5 was altered in SNL animals with allodynia induced by SNL, we next sought to determine whether the increase in the functional expression of the channels induced by Cdk5-mediated phosphorylation might produce changes in cAPs of nociceptive afferent fibers in SNL animals. In an initial series of experiments, the animal model used was validated by assessing the withdrawal of the limb in response to stimulation with von Frey filaments, and the effect of the nerve ligation on the development of mechanical allodynia on days 1, 3, 7, and 14 was evaluated. Hence, stimulation on the plantar surface of the left hindlimb (ipsilateral) of the control (naive) group animals produced a $50 \%$ paw withdrawal threshold of $\sim 14$ g that was maintained throughout the evaluation period ( $14 \mathrm{~d}$ ). Likewise, in sham-operated animals, the ipsilateral paw withdrawal threshold did not change significantly. In sharp contrast, the ligation of the spinal nerves decreased this withdrawal threshold (to $<4 \mathrm{~g}$ ) in the ipsilateral limb in response to stimulation with von Frey filaments (Fig. 9A).

We then studied the potential role of T-type channels on the excitability of the sensory nerve fibers. To this end, the cAPs evoked by stimulation of the spinal nerve L5 was recorded in the corresponding dorsal root in animals with allodynia induced by SNL (Fig. 9B). The cAPs recorded in the nerves of animals with surgically induced mechanical allodynia showed a smaller area under the curve (AUC; $78 \%$ ), with respect to those recorded in the control condition after peripheral nerve stimulation at $3 \times \mathrm{T}$, where most of the primary afferent fast-conducting (proprioceptive) fibers are activated. In contrast, the AUC of cAPs recorded in sensory C-type (nociceptive) fibers, obtained by stimulation at $50 \times \mathrm{T}$, were significantly increased (approximately twofold) with respect to the sham-operated rats (compare the corresponding traces in Fig. 9C,D).

Next, the possible contribution of different $\mathrm{Ca}_{\mathrm{V}}$ channels to the $\mathrm{CAP}$ of the sensory $\mathrm{C}$-type fibers was investigated using mibefradil (500 nM) and $\omega$-conotoxin (Ctx)-GVIA (250 nM), which are antagonists of $\mathrm{T}$ - and $\mathrm{N}$-type channels, respectively. Interestingly, mibefradil significantly reduced $(\sim 30 \%)$ the AUC of cAPs in the nerves from animals with experimentally induced allodynia (Fig. 9D), while in the nerves of the sham-operated animals (Fig. 9C) the effect was a little smaller $(\sim 25 \%)$. On the other hand, the sequential addition of the N-type channel blocker resulted in a larger reduction $(\sim 50 \%)$ of the AUC of the cAPs in the recordings obtained from both the SNL and sham-operated ani- 
A
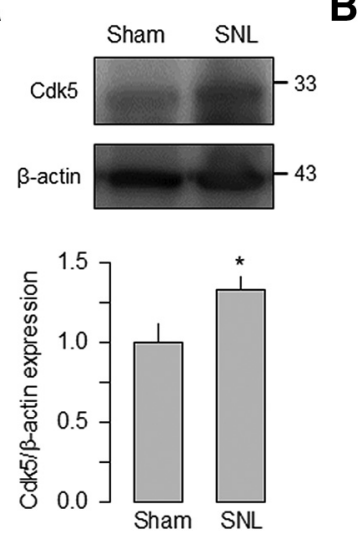

B
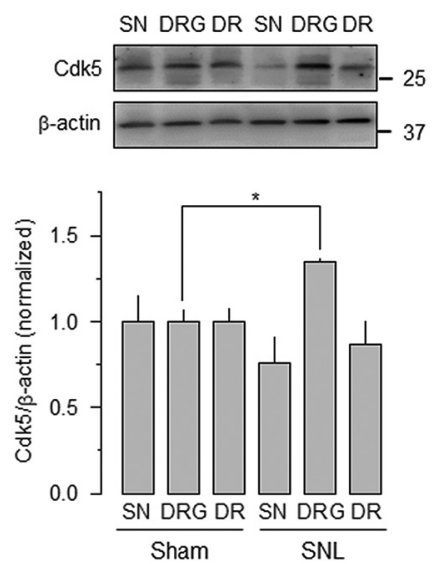

Figure 7. SNL increases the relative expression of Cdk5 in the DRG. $\boldsymbol{A}$, Top, Comparative Western blot analysis of C $\mathrm{dk} 5$ expression in sham-operated animals and animals with mechanical allodynia induced by the ligation of the spinal nerves $\mathrm{L} 5-\mathrm{L} 6$. $\mathrm{Cdk} 5$ was detected in cell lysates from DRG L5-L6 $14 \mathrm{~d}$ after SNL using specific antibodies ( $n=3$ independent experiments). $\beta$-actin was used as a loading control. The asterisk denotes a significant difference from the control condition (Table 1). B, Top, Comparative Western blot analysis of Cdk5 protein expression in sham-operated animals and rats with mechanical allodynia induced by the ligation of the spinal nerves $L 5-L 6$, in lysates from the spinal nerve $S N$, the DRG, and the DR. Cdk5 was detected in lysates from L5-L6 (B) $14 \mathrm{~d}$ after SNL using specific antibodies. Bottom, Corresponding protein band signal intensities of $\mathrm{Cdk} 5$ normalized to $\beta$-actin levels to obtain the relative expression of the kinase. The bar charts summarize the results of three independent experiments, and the asterisks denote significant differences (Table 1).

mals (Fig. 9E,F). Here, it is worth mentioning that mibefradil blocks T-type channel activity with an $\mathrm{IC}_{50}$ of $\sim 300 \mathrm{nM}$, and that it has been shown to be $>10$-fold selective on T-type than on HVA channels (Todorovic et al., 2002). In addition, the drug is 3.5-fold more selective for the T-type channels than for other ion channels, including $\mathrm{Na}^{+}$and delayed rectifier $\mathrm{K}^{+}$channels (Perchenet and Clément-Chomienne, 2000; Strege et al., 2005).

\section{Effects of olomoucine on the cAP recorded from sensory C fibers}

We next investigated the role of the Cdk5-mediated regulation of the $\mathrm{Ca}_{\mathrm{V}} 3.2$ channels in the surgically induced mechanical allodynia using olomoucine. To this end, we first evaluated the presence of allodynia in the sham-operated and the SNL animals in the absence and presence of the $\mathrm{Cdk} 5$ inhibitor. Figure 10, $A$ and $B$, shows that chronic intrathecal administration of the drug in animals subjected to SNL partially reversed the decrease in the paw withdrawal threshold that usually occurs after surgery, during 3 consecutive days to drug administration.

We also investigated whether the changes observed in mechanical allodynia after the intrathecal administration of olomoucine were related to the Cdk5 ability to affect the functional expression of the $\mathrm{Ca}_{\mathrm{V}} 3.2$ channels in primary afferent fibers. The results of these experiments indicated that in the SN-DRG-DR preparation, the kinase blocker decreased the AUC of the cAPs recorded in nerves from SNL animals $(\sim 31 \%)$, while in nerves from sham-operated animals this effect was significantly smaller (Fig. 10C). Likewise, we investigated whether the modification in the cAPs caused by olomoucine was related to a possible reduction in the stimulatory actions of $\mathrm{Cdk} 5$ on $\mathrm{Ca}_{\mathrm{V}} 3.2$ channel activity. To this end, cAPs evoked by stimulation of the spinal nerves and recorded in the dorsal roots in sham-operated rats and in animals with SNL, were recorded in the presence of the T-channel blocker mibefradil alone or in combination with olo-

moucine. The results of this analysis showed that mibefradil caused a decrease in the amplitude of the $\mathrm{C}$ component of the cAPs (of $\sim 20 \%$ ) in both experimental groups, while the combined administration of mibefradil and olomoucine had no additive effects (Fig. 10D,E). Therefore, the T-type channel antagonist had an occlusive effect on the inhibition caused by Cdk5, suggesting that both compounds share a convergent mechanism of action.

\section{Discussion}

The biophysical properties of the T-type $\mathrm{Ca}_{\mathrm{V}}$ channels allow them to regulate neuronal excitability and contribute to the generation of subthreshold membrane potential oscillations that lead to $\mathrm{Na}^{+}$-dependent AP firing (Chemin et al., 2002; Cain and Snutch, 2010; Canto-Bustos et al., 2014; Lambert et al., 2014). These channels are expressed in peripheral sensory neurons, where they participate in nociceptive transmission and pain processing (Nelson et al., 2006; Bourinet et al., 2014, 2016; Carbone et al., 2014). Accordingly, the use of T-channel blockers alleviate the carrageenan-induced mechanical hyperalgesia (Watanabe et al., 2015), and the knockdown of $\mathrm{Ca}_{\mathrm{V}} 3.2$ channels restores normal paw withdrawal thresholds for tactile stimuli in an animal model of chronic pain induced by peripheral nerve constriction (Bourinet et al., 2005). Here, our studies on the contribution of the T-type $\mathrm{Ca}_{\mathrm{V}}$ channels to the excitability of sensory nerve fibers show that the cAPs evoked by stimulation of the spinal nerves and recorded in the corresponding dorsal root in animals with SNL (L5-L6), induces a significant increase in the $\mathrm{C}$ component compared with controls. We hypothesized that this observation might be explained by an increase in the functional activity of T-type $\mathrm{Ca}_{\mathrm{V}} 3.2$ channels class caused by Cdk5/p35-mediated phosphorylation.

In particular, our data indicate that $\mathrm{Cdk} 5 / \mathrm{p} 35$ phosphorylates $\mathrm{Ca}_{\mathrm{V}} 3.2$ in residues S561 and S1987, resulting in increased membrane expression of the channels. These data are consistent with previous studies on the regulation of $\mathrm{Ca}_{\mathrm{V}} 3.2$ channels by phosphorylation using mass spectrometry. Blesneac et al. (2015) reported that these serine residues may be phosphorylated in the mouse brain and recombinant human $\mathrm{Ca}_{\mathrm{v}} 3.2$ channels expressed in HEK293 cells. Likewise, we previously reported that Cdk5 phosphorylates the $\mathrm{Ca}_{\mathrm{V}} 3.1$ isoform in a serine residue at position 2234 (Calderón-Rivera et al., 2015). In contrast, the possibility of a direct effect of $\mathrm{Cdk} 5$ on $\mathrm{Ca}_{\mathrm{V}} 3.2$ channels is unlikely given that Cdk5 seems not to affect the activity of target proteins by any mechanism independent of its kinase activity. In this context, it is also worth recalling that Cdk5 may interact with other proteins such as Cyclin E and GSTP1 that act as regulators of its activity by competing for the binding site of its activator p35 (Shupp et al., 2017). However, the functional experiments in the present report were mostly performed in cells overexpressing the Cdk5/p35 complex, which minimizes the possible effects of the regulatory proteins on Cdk5 activity.

In the functional context, a previous report by Blesneac et al. (2015) showed that the phosphorylation of a locus (S442/S445/ T446) within the "gating brake," a functional domain in the intracellular loop connecting repeats I and II of $\mathrm{Ca}_{\mathrm{V}} 3.2$ (Vitko et al., 2007; Arias-Olguín et al., 2008), is of particular importance for the gating of the channels. These studies also showed the presence of 34 phosphorylatable sites for the native channel in the rat brain and 43 for the recombinant human $\mathrm{Ca}_{\mathrm{V}} 3.2$ channel. However, except for residues S442, S445, and T446, the rest of the phosphosites had no effect on the biophysical properties of the channels, suggesting that the functional role of some of them in $\mathrm{Ca}_{\mathrm{V}} 3.2$ 
A
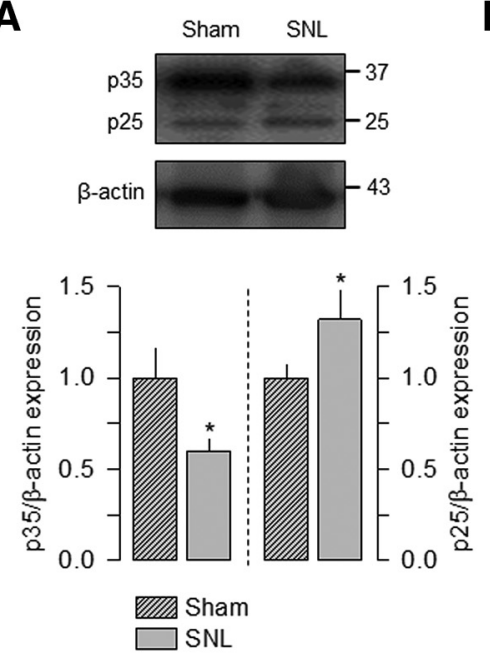

B

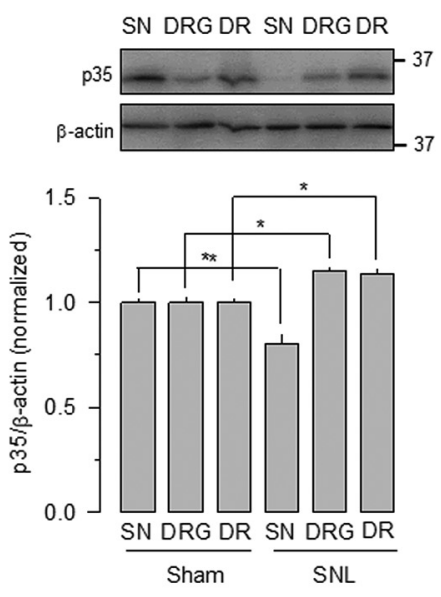

C

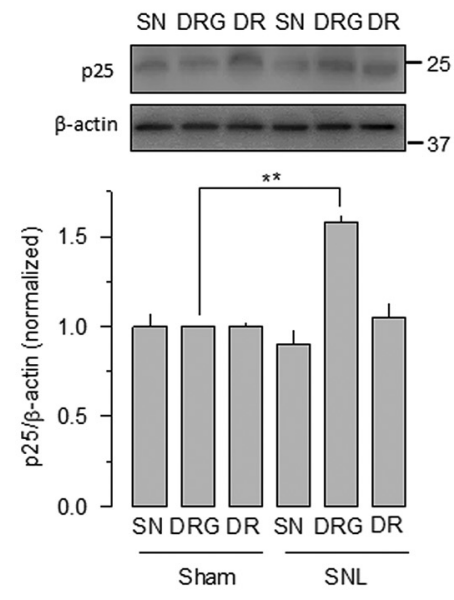

Figure 8. SNL increases the relative expression of $\mathrm{p} 35$ and $\mathrm{p} 25$ in the DRG. $A$, Top, Comparative Western blot analysis of $\mathrm{p} 35$ and 25 expression in sham-operated animals and rats with allodynia induced by the ligation of the spinal nerves $\mathrm{L} 5-\mathrm{L} 6$. The C $\mathrm{dk} 5$ activators were detected in cell lysates from DRG of $\mathrm{L} 5-\mathrm{L} 614 \mathrm{~d}$ after SNL using specific antibodies. Bottom, Corresponding protein band signal intensities of proteins normalized to $\beta$-actin levels ( $n=3$ and 4 independent experiments for $\mathrm{p} 35$ and $\mathrm{p} 25$, respectively). SNL increases the relative expression of $p 25$ in the DRG at the expense of an apparent decrease in p35. The asterisk denotes a significant difference from the control condition (Table 1). B, C, Top panels, Comparative Western blot analysis of p35 and p25 protein expression in sham-operated animals and rats with mechanical allodynia induced by the ligation of the spinal nerves $L 5-L 6$, in lysates from the spinal nerve $S N$, the DRG, and the DR. Proteins were detected in lysates from L5-L6 $14 \mathrm{~d}$ after SNL using specific antibodies to p35 and p25 as indicated. Bottom panels, Corresponding protein band signal intensities of p35 and p25 normalized to $\beta$-actin levels to obtain the relative expression of the kinase activators. The bar charts summarize the results of three independent experiments, and the asterisks denote significant differences. Two-way ANOVA was performed for multiple comparisons followed by Bonferroni's tests for pairwise comparisons (Table 1).

A

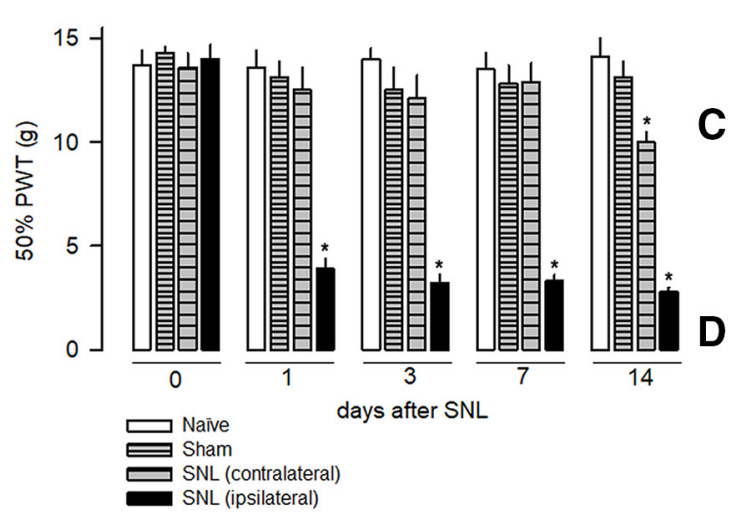

B

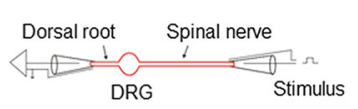

C
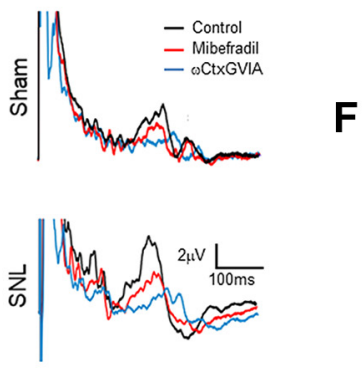

E
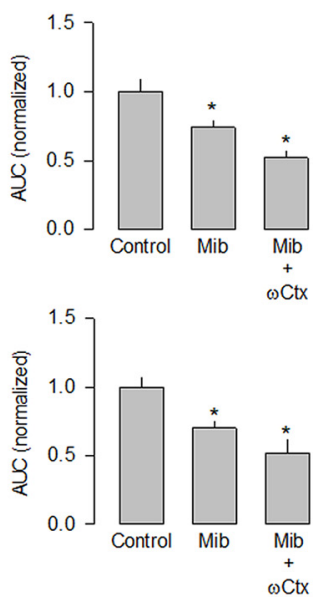

Figure 9. Contribution of T-type $\mathrm{Ca}_{\mathrm{V}}$ channels to the ( component of the CAP. A, Mechanical allodynia induced by SNL. Stimulation with von Frey filaments to the plantar surface of the left lower limb (ipsilateral) of control (naive) animals produced a $50 \%$ paw withdrawal threshold (PWT) of $\sim 14 \mathrm{~g}$ that was maintained throughout the time of evaluation (14 d). The $50 \%$ PWT in the ipsilateral side of sham-operated animals did not change significantly. In contrast, SNL significantly decreased (to $<4 \mathrm{~g}$ ) the $50 \%$ PWT in the ipsilateral lower limbs in response to stimulation with the von Frey filaments. This altered threshold remained virtually constant from 1 to $14 \mathrm{~d}$, while in the contralateral side there was a significant decrease in the $50 \%$ PWT only at $14 \mathrm{~d}$ (contralateralization). One-way ANOVA was performed followed by Bonferroni's tests for comparisons (Table $1 ; n=6$ independent experiments). $\boldsymbol{B}$, Schematic diagram of the experimental setup. Extracellular recordings of CAPs were performed using $300 \mathrm{~ms}$ duration stimulation pulses $(1.5,3,10$, and $50 \times \mathrm{T})$ applied at a frequency of $0.2 \mathrm{~Hz}$. C, D, Representative traces of cAPs recorded in C-type fibers from sham-operated animals and rats with mechanical allodynia induced by ligation of the spinal nerves, as indicated. In both graphs, the black traces illustrate the control condition, the red trace is the voltage trace after the application of the T-type channel antagonist mibefradil (Mib; $500 \mathrm{~nm}$ ), and the blue trace is after application of the N-type channels blocker $\omega \mathrm{Ctx}$-GVIA (250 nM). The toxin was added after mibefradil, therefore at the end the action of the two compound was evaluated together. The size of the C component in rats with mechanical allodynia is bigger than the trace in the sham-operated animals. In addition, a decrease in the $\left(\right.$ component is observed after application of the $C_{\mathrm{V}}$ channel inhibitors. $\boldsymbol{E}, \boldsymbol{F}$, The effect of mibefradil and $\omega C \mathrm{Ctx}$-GVIA on the cAPs recorded from sham animals and animals with mechanical allodynia $(\boldsymbol{E}, n=180 ; \boldsymbol{F}, 210$ traces). The bar charts show the comparison of the normalized area under the $($ component of $C A P s$ (AUC) in the control condition and after the application of mibefradil alone or in combination with $\omega$ Ctx-GVIA. The asterisk denotes a significant difference from the control condition (Table 1).

could be related to other forms of regulation. Indeed, our data suggest that the phosphorylation of residues S561 and S1987, which may occur in response to an exacerbated expression of Cdk5/p35 after SNL, favors the membrane localization and causes a clustered distribution of the channels in the soma of nociceptive neurons. Interestingly, S561 is located in the central portion of the intracellular loop that connects repeats I and II, which play important functional roles in $\mathrm{Ca}_{\mathrm{v}} 3.2$, including trafficking of the channels to the plasma membrane (Vitko et al., 2007; Baumgart et al., 2008).

Phosphorylation is an important mechanism of regulation not only of activity but also the membrane location of $\mathrm{Ca}_{\mathrm{V}}$ channels. It has been shown that mimicking the phosphorylation sites at the $\mathrm{C}$-terminal domain of the neuronal $\mathrm{Ca}_{\mathrm{V}} 1.2$ channels affects 
the mobility and reveals a dynamic organization of the channels in different signaling complexes (Folci et al., 2018; Heine et al., 2019). This suggests that a tighter or looser association of the channels to different signaling complexes may affect the intracellular signaling process. In addition, the rearrangement of L-type channels in microdomains has been shown to be an important event in pathways that may contribute to cardiac ventricular arrhythmogenesis.

T-type channels are expressed throughout the peripheral nervous system and CNS. Their low activation threshold makes them suitable for functioning around the resting membrane potential (Stuart et al., 1997; Leresche and Lambert, 2017). These channels provide a "window current" that allows the passive entry of $\mathrm{Ca}^{2+}$, which contributes to maintain the membrane potential at rest, and influences neuronal excitability. Although a substantial fraction of these channels is inactivated at rest, their recovery from inactivation during brief periods of hyperpolarization generates rebound APs that contribute to the pacemaker capacity of some neuronal types (Chemin et al., 2002; Cain and Snutch, 2010; Canto-Bustos et al., 2014; Lambert et al., 2014). In addition, it has been shown that these channels have the ability to associate and regulate the activity of some $\mathrm{K}_{\mathrm{V}}$ channels contributing to shape the AP firing (Anderson et al., 2010).

Interestingly, our results indicate that $\mathrm{Cdk} 5 / \mathrm{p} 35$-mediated $\mathrm{Ca}_{\mathrm{V}} 3.2$ phosphorylation, in addition to favoring channel membrane location, could contribute to guiding the channels to defined subcellular compartments. After SNL, there is a redistribution of $\mathrm{Ca}_{\mathrm{V}} 3.2$ channels in the afferent fibers, as follows: in animals with mechanical allodynia after SNL, the channel proteins were grouped in the soma of the sensory neurons; while in the peripheral region of the nerves their density was significantly lower. These findings suggest that the traffic of the channels to the periphery may be altered or that their mobility from the periphery to the soma might be increased as a consequence of phosphorylation. Here, it is worth recalling that T-type channels contribute to the dendritic depolarization associated with action potential propagation (Stuart et al., 1997; Leresche and Lambert, 2017). Hence, the differential distribution of $\mathrm{Ca}_{\mathrm{V}} 3.2$ channels in response to phosphorylation mediated by the Cdk-5/p35 complex could help to explain the increased excitability (manifested as a larger C component of the cAP) of afferent fibers in animals with mechanical allodynia.

On the other hand, previous studies have shown that HVA channel activity may also be regulated by the Cdk5/p35 complex. It has been reported that the L-, P/Q-, and N-type channels are regulated by $\mathrm{Cdk} 5$ and that this regulation has relevant presynaptic implications (Su et al., 2012; Furusawa et al., 2014). This regulation seems to be mediated by an interaction between the experimental condition)
B

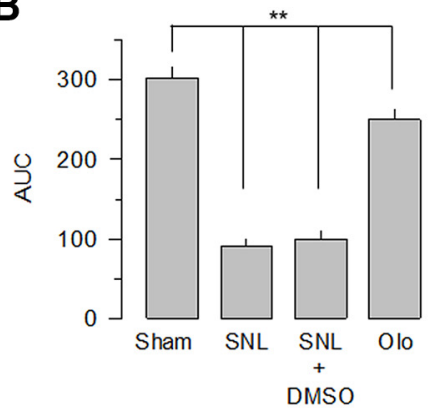

E

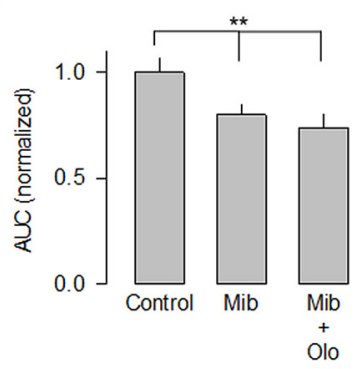

Figure 10. Intrathecal injection of olomoucine $(0 \mathrm{lo})$ reduces mechanical allodynia. $\boldsymbol{A}$, Percentage of the paw withdrawal threshold \pm SEM in sham-operated (filled circles) and in spinal nerve-ligated animals (open circles) after intrathecal injection of (Table $1 ; n=$ (he bar charts compare the normalized area under the C component. Kruskal-Wallis analysis was performed sham and SNL animals. Olomoucine (Olo) treatment occludes the effect of mibefradil (Mib) on the C component of the CAP. Representative traces of cAPs recorded in the absence (control, pink trace) or in the presence of $500 \mathrm{~nm}$ mibefradil (green trace) alone, or in combination with $100 \mu$ olomoucine (purple trace) from SNL animals. $\boldsymbol{E}$, Blockade of $\mathrm{a}_{\mathrm{v}} 3.2$ channel activity with Mib effect on the CAPs area, suggesting that they share the same mechanism of action. Kruskal-Wallis analysis was performed for multiple comparison followed by Dunn's post hoc tests for pairwise comparisons ( ${ }^{* *} p<0.001$, Table $1 ; n=120$ traces in each

channel and RIM1, a protein that influences vesicle docking at the active zone (Gandini and Felix, 2012; Su et al., 2012). It should also be noted that there is experimental evidence suggesting that the $\mathrm{Ca}_{\mathrm{V}} \alpha_{2} \delta$ - 1 auxiliary subunit of $\mathrm{HVA} \mathrm{Ca} \mathrm{V}_{\mathrm{V}}$ channels may play a role in the pathophysiology of neuropathic pain (Field et al., 2006; Li et al., 2006; Gong et al., 2018; González-Ramírez et al., 2018).

In addition to the role Cdk5-mediated phosphorylation on CaV3.2, it may affect TRPV1 (transient receptor potential cation channel subfamily $\mathrm{V}$ member 1 ) and other channels related to chronic pain, including $\mathrm{K}_{\mathrm{V}}$ and other $\mathrm{Ca}_{\mathrm{V}}$ channels (Buraei et al., 2007). It should be mentioned that though Cdk5 can indeed phosphorylate TRPV1 (Pareek et al., 2006, 2007; Xing et al., 2012), evidence that these channels may play a role in determining the $\mathrm{C}$ component of a cAP in which primary afferent fibers are lacking. Likewise, it has been reported that Kv2.1 and Kv7.2 neuronal channels are molecular targets of Cdk5 (Cerda and Trimmer, 2011; Erdem et al., 2017). However, the role that these channel play in neuropathic pain remains uncertain. Last, recent evidence suggests that Cdk5 may also play a role in chronic pain by acting on CRMP2 (collapsing response mediator protein 2; Brittain et al., 2012). Interestingly, this functional interaction re- 
sults in reduced presynaptic distribution of $\mathrm{Ca}_{\mathrm{V}} 2.2$ and $\mathrm{Na}_{\mathrm{V}} 1.7$ (Yu et al., 2019). Although this regulation of ion channels by Cdk5 would have an opposite effect to that observed by the direct phosphorylation of Cav3.2 channels, studying how these mechanisms are related is an interesting topic for future studies.

The increase in the intracellular concentration of $\mathrm{Ca}^{2+}$ may promote the enhanced activity of calpain with the consequent cleavage of p 35 into p25, which forms a more stable complex with Cdk 5 by increasing its activity. When we evaluated the effect of intrathecal olomoucine on the cAPs in the preparations of $\mathrm{SN}-$ DRG-DR, the Cdk5 inhibitor was able to occlude the inhibitory effect of the T-channel antagonist mibefradil, suggesting that both compounds share a common mechanism of action. Moreover, olomoucine partially reversed SNL-induced mechanical allodynia. Together, these data show that the increase in the activity of T-type $\mathrm{Ca}_{\mathrm{v}} 3.2$ channels induced by Cdk5-mediated phosphorylation contributes to the increase of the $\mathrm{C}$ component of the cAP recorded in the dorsal roots of animals, with allodynia produced by SNL. These findings may help to explain how the alteration induced by nerve injury may cause neuropathic pain. Therefore, in addition to the $\mathrm{Ca}_{\mathrm{V}} 3.2$ channels, Cdk5 and/or its activators could be attractive targets in the development of more effective interventions to relieve pain induced by nerve injury and other diseases of the nervous system associated with chronic pain.

\section{References}

Anderson D, Mehaffey WH, Iftinca M, Rehak R, Engbers JD, Hameed S, Zamponi GW, Turner RW (2010) Regulation of neuronal activity by $\mathrm{Ca}_{\mathrm{V}} 3-\mathrm{K}_{\mathrm{V}} 4$ channel signaling complexes. Nat Neurosci 13:333-337.

Arias-Olguín II, Vitko I, Fortuna M, Baumgart JP, Sokolova S, Shumilin IA, Van Deusen A, Soriano-García M, Gomora JC, Perez-Reyes E (2008) Characterization of the gating brake in the I-II loop of Cav3.2 T-type $\mathrm{Ca}^{2+}$ channels. J Biol Chem 283:8136-8144.

Avila G, Sandoval A, Felix R (2004) Intramembrane charge movement associated with endogenous $\mathrm{K}^{+}$channel activity in HEK-293 cells. Cell Mol Neurobiol 24:317-330.

Basbaum AI, Bautista DM, Scherrer G, Julius D (2009) Cellular and molecular mechanisms of pain. Cell 139:267-284.

Baumgart JP, Vitko I, Bidaud I, Kondratskyi A, Lory P, Perez-Reyes E (2008) I-II loop structural determinants in the gating and surface expression of low voltage-activated calcium channels. PLoS One 3:e2976,

Blesneac I, Chemin J, Bidaud I, Huc-Brandt S, Vandermoere F, Lory P (2015) Phosphorylation of the $\mathrm{Ca}_{\mathrm{V}} 3.2 \mathrm{~T}$-type calcium channel directly regulates its gating properties. Proc Natl Acad Sci U S A 112:13705-13710.

Bourinet E, Alloui A, Monteil A, Barrère C, Couette B, Poirot O, Pages A, McRory J, Snutch TP, Eschalier A, Nargeot J (2005) Silencing of the Cav3.2 T-type calcium channel gene in sensory neurons demonstrates its major role in nociception. EMBO J 24:315-324.

Bourinet E, Altier C, Hildebrand ME, Trang T, Salter MW, Zamponi GW (2014) Calcium-permeable ion channels in pain signaling. Physiol Rev 94:81-140.

Bourinet E, Francois A, Laffray S (2016) T-type calcium channels in neuropathic pain. Pain 157 [Suppl 1]:S15-S22.

Brittain JM, Wang Y, Eruvwetere O, Khanna R (2012) Cdk5-mediated phosphorylation of CRMP-2 enhances its interaction with $\mathrm{Ca}_{\mathrm{V}} 2.2$. FEBS Lett 586:3813-3818.

Buraei Z, Schofield G, Elmslie KS (2007) Roscovitine differentially affects $\mathrm{Ca}_{\mathrm{V}} 2$ and $\mathrm{kv}$ channels by binding to the open state. Neuropharmacology 52:883-894.

Cain SM, Snutch TP (2010) Contributions of T-type calcium channel isoforms to neuronal firing. Channels (Austin) 4:475-482.

Calderón-Rivera A, Sandoval A, González-Ramírez R, González-Billault C, Felix R (2015) Regulation of neuronal $\mathrm{Ca}_{\mathrm{v}} 3.1$ channels by cyclindependent kinase 5 (Cdk5). PLoS One 10:e0119134.

Canto-Bustos M, Loeza-Alcocer E, González-Ramírez R, Gandini MA, Delgado-Lezama R, Felix R (2014) Functional expression of T-type $\mathrm{Ca}^{2+}$ channels in spinal motoneurons of the adult turtle. PLoS One 9:e108187.
Carbone E, Calorio C, Vandael DH (2014) T-type channel-mediated neurotransmitter release. Pflugers Arch 466:677-687.

Cerda O, Trimmer JS (2011) Activity-dependent phosphorylation of neuronal Kv2.1 potassium channels by CDK5. J Biol Chem 286:28738-28748.

Chaplan SR, Bach FW, Pogrel JW, Chung JM, Yaksh TL (1994) Quantitative assessment of tactile allodynia in the rat paw. J Neurosci Methods 53:55-63.

Chemin J, Monteil A, Perez-Reyes E, Bourinet E, Nargeot J, Lory P (2002) Specific contribution of human T-type calcium channel isotypes a1G, a1H and alI to neuronal excitability. J Physiol 540:3-14.

Chemin J, Mezghrani A, Bidaud I, Dupasquier S, Marger F, Barrère C, Nargeot J, Lory P (2007) Temperature-dependent modulation of $\mathrm{Ca}_{\mathrm{V}} 3$ T-type calcium channels by protein kinases $\mathrm{C}$ and $\mathrm{A}$ in mammalian cells. J Biol Chem 282:32710-32718.

Chen W, Chi YN, Kang XJ, Liu QY, Zhang HL, Li ZH, Zhao ZF, Yang Y, Su L, Cai J, Liao FF, Yi M, Wan Y, Liu FY (2018) Accumulation of $\mathrm{Ca}_{\mathrm{V}} 3.2$ T-type calcium channels in the uninjured sural nerve contributes to neuropathic pain in rats with spared nerve injury. Front Mol Neurosci 11:24.

Dogrul A, Gardell LR, Ossipov MH, Tulunay FC, Lai J, Porreca F (2003) Reversal of experimental neuropathic pain by T-type calcium channel blockers. Pain 105:159-168.

Erdem FA, Salzer I, Heo S, Chen WQ, Jung G, Lubec G, Boehm S, Yang JW (2017) Updating in vivo and in vitro phosphorylation and methylation sites of voltage-gated Kv7.2 potassium channels. Proteomics 17:1700015.

Field MJ, Cox PJ, Stott E, Melrose H, Offord J, Su TZ, Bramwell S, Corradini L, England S, Winks J, Kinloch RA, Hendrich J, Dolphin AC, Webb T, Williams D (2006) Identification of the $\alpha_{2}-\delta$-1 subunit of voltagedependent calcium channels as a molecular target for pain mediating the analgesic actions of pregabalin. Proc Natl Acad Sci U S A 103:1753717542.

Folci A, Steinberger A, Lee B, Stanika R, Scheruebel S, Campiglio M, Ramprecht C, Pelzmann B, Hell JW, Obermair GJ, Heine M, Di Biase V (2018) Molecular mimicking of C-terminal phosphorylation tunes the surface dynamics of $\mathrm{Ca}_{\mathrm{V}} 1.2$ calcium channels in hippocampal neurons. J Biol Chem 293:1040-1053.

François A, Schüetter N, Laffray S, Sanguesa J, Pizzoccaro A, Dubel S, Mantilleri A, Nargeot J, Noël J, Wood JN, Moqrich A, Pongs O, Bourinet E (2015) The low-threshold calcium channel $\mathrm{Ca}_{\mathrm{V}} 3.2$ determines lowthreshold mechanoreceptor function. Cell Rep 10:S2211-S1247.

Furusawa K, Asada A, Saito T, Hisanaga S (2014) The effect of cyclindependent kinase 5 on voltage-dependent calcium channels in PC12 cells varies according to channel type and cell differentiation state. J Neurochem 130:498-506.

Gandini MA, Felix R (2012) Functional interactions between voltage-gated $\mathrm{Ca}^{2+}$ channels and Rab3-interacting molecules (RIMs): new insights into stimulus-secretion coupling. Biochim Biophys Acta 1818:551-558.

Gong N, Park J, Luo ZD (2018) Injury-induced maladaptation and dysregulation of calcium channel $\alpha_{2} \delta$ subunit proteins and its contribution to neuropathic pain development. Br J Pharmacol 175:2231-2243.

González-Ramírez R, Martínez-Hernández E, Sandoval A, Gómez-Mora K, Felix R (2018) Regulation of the voltage-gated $\mathrm{Ca}^{2+}$ channel $\mathrm{Ca}_{\mathrm{V}} \alpha_{2} \delta$-1 subunit expression by the transcription factor egr-1. Neurosci Lett 673: $136-141$.

Heine M, Heck J, Ciuraszkiewicz A, Bikbaev A (2019) Dynamic compartmentalization of calcium channel signalling in neurons. Neuropharmacology, in press.

Iftinca MC, Zamponi GW (2009) Regulation of neuronal T-type calcium channels. Trends Pharmacol Sci 30:32-40.

Jacus MO, Uebele VN, Renger JJ, Todorovic SM (2012) Presynaptic Ca 3.2 channels regulate excitatory neurotransmission in nociceptive dorsal horn neurons. J Neurosci 32:9374-9382.

Jagodic MM, Pathirathna S, Joksovic PM, Lee W, Nelson MT, Naik AK, Su P, Jevtovic-Todorovic V, Todorovic SM (2008) Upregulation of the T-type calcium current in small rat sensory neurons after chronic constrictive injury of the sciatic nerve. J Neurophysiol 99:3151-3156.

Kim SH, Chung JM (1992) An experimental model for peripheral neuropathy produced by segmental spinal nerve ligation in the rat. Pain 50: 355-363.

Lambert RC, Bessaih T, Leresche N (2006) Modulation of neuronal T-type calcium channels. CNS Neurol Disord Drug Targets 5:611-627.

Lambert RC, Bessaïh T, Crunelli V, Leresche N (2014) The many faces of T-type calcium channels. Pflugers Arch 466:415-423. 
Leresche N, Lambert RC (2017) T-type calcium channels in synaptic plasticity. Channels (Austin) 11:121-139.

Li CY, Zhang XL, Matthews EA, Li KW, Kurwa A, Boroujerdi A, Gross J, Gold MS, Dickenson AH, Feng G, Luo ZD (2006) Calcium channel $\alpha_{2} \delta 1$ subunit mediates spinal hyperexcitability in pain modulation. Pain 125 : $20-34$.

Liu QY, Chen W, Cui S, Liao FF, Yi M, Liu FY, Wan Y (2019) Upregulation of $\mathrm{Ca}_{\mathrm{V}} 3.2 \mathrm{~T}$-type calcium channels in adjacent intact $\mathrm{L} 4$ dorsal root ganglion neurons in neuropathic pain rats with L5 spinal nerve ligation. Neurosci Res 142:30-37.

McLinden KA, Trunova S, Giniger E (2012) At the fulcrum in health and disease: Cdk5 and the balancing acts of neuronal structure and physiology. Brain Disord Ther 2012 [Suppl 1]:001.

Mestre C, Pélissier T, Fialip J, Wilcox G, Eschalier A (1994) A method to perform direct transcutaneous intrathecal injection in rats. J Pharmacol Toxicol Methods 32:197-200.

Millan MJ (1999) The induction of pain: an integrative review. Prog Neurobiol 57:1-164.

Nelson MT, Todorovic SM, Perez-Reyes E (2006) The role of T-type calcium channels in epilepsy and pain. Curr Pharm Des 12:2189-2197.

Nelson MT, Joksovic PM, Su P, Kang HW, Van Deusen A, Baumgart JP, David LS, Snutch TP, Barrett PQ, Lee JH, Zorumski CF, Perez-Reyes E, Todorovic SM (2007) Molecular mechanisms of subtype-specific inhibition of neuronal T-type calcium channels by ascorbate. J Neurosci 27:12577-12583.

Pareek TK, Keller J, Kesavapany S, Pant HC, Iadarola MJ, Brady RO, Kulkarni AB (2006) Cyclin-dependent kinase 5 activity regulates pain signaling. Proc Natl Acad Sci U S A 103:791-796.

Pareek TK, Keller J, Kesavapany S, Agarwal N, Kuner R, Pant HC, Iadarola MJ, Brady RO, Kulkarni AB (2007) Cyclin-dependent kinase 5 modulates nociceptive signaling through direct phosphorylation of transient receptor potential vanilloid 1. Proc Natl Acad Sci U S A 104:660-665.

Perchenet L, Clément-Chomienne O (2000) Characterization of mibefradil block of the human heart delayed rectifier hKv1.5. J Pharmacol Exp Ther 295:771-778.

Perez-Reyes E, Cribbs LL, Daud A, Lacerda AE, Barclay J, Williamson MP, Fox M, Rees M, Lee JH (1998) Molecular characterization of a neuronal low-voltage-activated T-type calcium channel. Nature 391:896-900.

Scroggs RS, Fox AP (1992) Calcium current variation between acutely isolated adult rat dorsal root ganglion neurons of different size. J Physiol 445:639-658.

Shiue SJ, Wang CH, Wang TY, Chen YC, Cheng JK (2016) Chronic intrathecal infusion of T-type calcium channel blockers attenuates $\mathrm{Ca}_{\mathrm{V}} 3.2$ upregulation in nerve-ligated rats. Acta Anaesthesiol Taiwan 54:81-87.

Shupp A, Casimiro MC, Pestell RG (2017) Biological functions of CDK5 and potential CDK5 targeted clinical treatments. Oncotarget 8:1737317382 .

Strege PR, Bernard CE, Ou Y, Gibbons SJ, Farrugia G (2005) Effect of mibefradil on sodium and calcium currents. Am J Physiol Gastrointest Liver Physiol 289:G249-G253.

Stuart G, Spruston N, Sakmann B, Häusser M (1997) Action potential initiation and backpropagation in neurons of the mammalian CNS. Trends Neurosci 20:125-131.
Su SC, Seo J, Pan JQ, Samuels BA, Rudenko A, Ericsson M, Neve RL, Yue DT, Tsai LH (2012) Regulation of N-type voltage-gated calcium channels and presynaptic function by cyclin-dependent kinase 5. Neuron 75:675687.

Takahashi T, Aoki Y, Okubo K, Maeda Y, Sekiguchi F, Mitani K, Nishikawa H, Kawabata A (2010) Upregulation of $\mathrm{Ca}_{\mathrm{v}} 3.2$ T-type calcium channels targeted by endogenous hydrogen sulfide contributes to maintenance of neuropathic pain. Pain 150:183-191.

Talley EM, Cribbs LL, Lee JH, Daud A, Perez-Reyes E, Bayliss DA (1999) Differential distribution of three members of a gene family encoding low voltage-activated (T-type) calcium channels. J Neurosci 19:1895-1911.

Todd AJ (2010) Neuronal circuitry for pain processing in the dorsal horn. Nat Rev Neurosci 11:823-836.

Todorovic SM, Jevtovic-Todorovic V (2013) Neuropathic pain: role for presynaptic T-type channels in nociceptive signaling. Pflugers Arch 465:921-927.

Todorovic SM, Meyenburg A, Jevtovic-Todorovic V (2002) Mechanical and thermal antinociception in rats following systemic administration of mibefradil, a T-type calcium channel blocker. Brain Res 951:336-340.

Vitko I, Bidaud I, Arias JM, Mezghrani A, Lory P, Perez-Reyes E (2007) The I-II loop controls plasma membrane expression and gating of $\mathrm{Ca}_{\mathrm{V}} 3.2$ T-type $\mathrm{Ca}^{2+}$ channels: a paradigm for childhood absence epilepsy. J Neurosci 27:322-330.

Watanabe M, Ueda T, Shibata Y, Kumamoto N, Shimada S, Ugawa S (2015) Expression and Regulation of $\mathrm{Ca}_{\mathrm{V}} 3.2$ T-type calcium channels during inflammatory hyperalgesia in mouse dorsal root ganglion neurons. PLoS One 10:e0127572.

Wen XJ, Xu SY, Chen ZX, Yang CX, Liang H, Li H (2010) The roles of T-type calcium channel in the development of neuropathic pain following chronic compression of rat dorsal root ganglia. Pharmacology 85:295300.

Woolf CJ (2004) Pain: moving from symptom control toward mechanism specific pharmacologic management. Ann Intern Med 140:441-451.

Xing BM, Yang YR, Du JX, Chen HJ, Qi C, Huang ZH, Zhang Y, Wang Y (2012) Cyclin-dependent kinase 5 controls TRPV1 membrane trafficking and the heat sensitivity of nociceptors through KIF13B. J Neurosci 32:14709-14721.

Yao J, Davies LA, Howard JD, Adney SK, Welsby PJ, Howell N, Carey RM, Colbran RJ, Barrett PQ (2006) Molecular basis for the modulation of native T-type $\mathrm{Ca}^{2+}$ channels in vivo by $\mathrm{Ca}^{2+} /$ calmodulin-dependent protein kinase II. J Clin Invest 116:2403-2412.

Yawn BP, Wollan PC, Weingarten TN, Watson JC, Hooten WM, Melton LJ 3rd (2009) The prevalence of neuropathic pain: clinical evaluation compared with screening tools in a community population. Pain Med 10:586-593.

Yu J, Moutal A, Dorame A, Bellampalli SS, Chefdeville A, Kanazawa I, Pham NYN, Park KD, Weimer JM, Khanna R (2019) Phosphorylated CRMP2 regulates spinal nociceptive neurotransmission. Mol Neurobiol 56: 5241-5255.

Zhang Y, Jiang X, Snutch TP, Tao J (2013) Modulation of low-voltageactivated T-type $\mathrm{Ca}^{2+}$ channels. Biochim Biophys Acta 1828:1550-1559.

Zimmermann M (1983) Ethical guidelines for investigations of experimental pain in conscious animals. Pain 16:109-110. 